\title{
Studies on the Spectral Interference of Gadolinium on Different Analytes by Inductively Coupled Plasma Atomic Emission Spectrometry
}

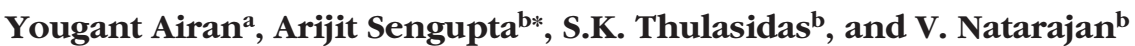 \\ ${ }^{a}$ Chemistry Department, Hindu College, University of Delhi, Delhi, India \\ ${ }^{b}$ Radiochemistry Division, Bhabha Atomic Research Centre, Trombay, Mumbai, India
}

\section{INTRODUCTION}

Among spectroscopic methods, which are most commonly used for trace metal characterization, inductively coupled plasma atomic emission spectrometry (ICP-AES) scores over other techniques due to its simplicity and simultaneous multielement determination capability coupled with adequate sensitivity, analytical range, and good precision of the determinations (1-5). Apart from these advantages, ICPAES suffers severely from spectral interference in trace level determinations of the analytes in the presence of emission-rich matrix elements (6-8). Different kinds of interferences in ICP-AES including chemical, nebulization, atomization, and spectral interferences are also reported in the literature (9-11). Quantitative chemical separation of an emission-rich major matrix, followed by the analysis of the raffinate, is the general methodology used in ICP-AES to minimize spectral interferences (12-17). This requires not only selective ligands for preferential extraction of the matrix, leaving the analytes in the raffinate without any loss even at trace levels, but is time-consuming with the chance of contamination during processing of the samples. Therefore, an ICP-AES-based method is necessary for the direct determination of analytes without any chemical separation which requires a detailed study on the spectral interference of the emission-rich matrix elements of the analytes.

\footnotetext{
*Corresponding author.
}

:E-mail: arijita@barc.gov.in

\section{ABSTRACT}

An attempt was made to understand the spectral interference of Gd on 29 common analytes ( $\mathrm{Ag}, \mathrm{Al}, \mathrm{B}, \mathrm{Ba}, \mathrm{Bi}, \mathrm{Ca}, \mathrm{Cd}$, $\mathrm{Ce}, \mathrm{Co}, \mathrm{Cr}, \mathrm{Cu}, \mathrm{Dy}, \mathrm{Fe}, \mathrm{Ga}, \mathrm{Gd}$, In, La, Li, Lu, Mg, Mn, Na, Nd, $\mathrm{Ni}, \mathrm{Pb}, \mathrm{Pr}, \mathrm{Sr}, \mathrm{Tl}$, and $\mathrm{Zn}$ ) using inductively coupled plasma atomic emission spectrometry (ICP-AES) with a capacitive charge-coupled device (CCD) as the detector. The present study includes identification of suitable interference-free analytical lines of these analytes, evaluation of the correction factor of each analytical line, and determination of the tolerance levels of these analytical lines along with the ICP-AES-based methodology for the simultaneous determination of Gd. Based on the spectral interference study, an ICP-AESbased method was developed for the determination of these analytes at trace levels in the presence of a Gd matrix without chemical separation. Furthermore, the developed methodology was validated using synthetic samples prepared from commercially available standard reference material solutions of individual elements; the results were found to be satisfactory. The method was also compared with other techniques.

The line-rich emission spectra of rare earth elements (REEs) and their multi-electron nature leads to the erroneous determination of analytes at trace levels owing to spectral interferences. Several studies reported on the mutual spectral interference of rare earth elements
(18-25). Gadolinium (Gd), being one of the important rare earth elements used in industry, is under consideration for studying its spectral interference on other analytes. It finds application as gadolinium yttrium garnets in microwaves, catalysts in petroleum cracking, phosphors for color TV tubes, and as alloy constituents for improving resistance to high temperatures and oxidation. The excellent neutron capture ability of ${ }^{155} \mathrm{Gd}$ and ${ }^{157} \mathrm{Gd}$ is utilized in the nuclear industry as urania-gadolinia fuel in nuclear control rods (26-28).

The advancement of the capacitive charge-coupled device (CCD) detector, which not only improves the analytical performance of the analytical lines, but also provides more options in choosing alternative interference-free analytical lines compared to the photomultiplier tube-based detector system (29-31).

In the present study, the spectral interference of $\mathrm{Gd}$ on 29 common analytes was studied in detail. Since the spectral interference is highly dependent on the concentration of Gd, an ICP-AES-based method was also developed for the simultaneous determination of Gd along with other analytes. Based on the spectral interference study and the analytical performance of the different analytical lines of the analytes, a new methodology was developed for the direct determination of these analytes without chemical separation. It was validated by using synthetic samples prepared from commercially available standard reference material of individual elements. 


\section{EXPERIMENTAL}

\section{Instrumental and Operating Conditions}

The analysis was carried out using a simultaneously multielemental atomic emission spectrometer (Spectro-Arcos, Germany) with a high-performing charge-coupled device (CCD) as the detector and inductively coupled plasma (ICP) as the source of excitation. The spectral interference as well as the overall analytical performance is highly dependent on the operating conditions. The plasma is operated at a frequency of $27.12 \mathrm{MHz}$. At a lower frequency, the skin depth will be more and the shape of the plasma changes to tear-shape which makes the sample introduction difficult. The power is optimized at $1.2 \mathrm{~kW}$ to sustain the plasma. Even though more power increases the signal intensity, the background also increases and as a result, the overall signal-to-noise ratio does not improve. Since in this case a pneumatic nebulizer is used, the nebulizer gas flow was optimized such that the aerosol of required diameter is generated and carried to the plasma. If the velocity for sample introduction is very low, the sample cannot be injected into the analytical zone of the plasma while high speed leads to the fact that the time of residence of the sample inside the plasma becomes small and the intensity of the analytical lines go down. In case of the present instrument, based on the overall performance of the analytes, the instrumental parameters were optimized in accordance with the recommendations of the manufacturer. There is very little flexibility in modifying the instrumental parameters. With the limited flexibility, an attempt was made to study (a) the input power vs net signalintensity, (b) nebulizer flow rate vs. net signal intensity for optimization of these parameters. The operating condi- tions and instrumental specifications are listed in Table I. The detector system, consisting of linear arrays of the CCD detector (3648 pixels/array), thermally stabilized together with an optical system, provides the ability to choose the alternate analytical lines (see Figure 1).

\section{Standard Solutions and Reagents}

Standard solutions for all of the elements were prepared from CertiPUR ${ }^{\circledR}$ ICP multi-standard solutions (E-Merck, Darmstadt, Germany) by proper dilution. Suprapur ${ }^{\circledR} \mathrm{HNO}_{3}$ (E-Merck, Darmstadt, Germany) and quartz doubledistilled water were used through- out the study. Multi-point standardization was carried out using $0.5 \mathrm{M}$ $\mathrm{HNO}_{3}$ as a lower standard and $0.05-1000 \mathrm{mg} / \mathrm{L}$ of the corresponding elemental standard as the higher standards for each line after proper peak search.

\section{Methods}

A series of SpecPure ${ }^{\circledR}$ Gd solutions (standard reference material elemental solution from E-Merck, Darmstadt, Germany) of concentrations between 0.05 to $1000 \mathrm{mg} / \mathrm{L}$ were prepared and fed into the argon plasma. The spectral interference of Gd was monitored by observing its contribution in different channels of the specified analytes. For each analyte, the least

TABLE I

Specifications and Operating Conditions of ICP-AES

\begin{tabular}{ll}
\hline Instrumental Specifications & \\
\hline Optical design & Paschen-Runge mounting, Circular design \\
Focal length & $750 \mathrm{~mm}$ \\
Grating & Holographic \\
Groove density & 1800 grooves/mm (1), 3600 grooves/mm (2) \\
Wavelength range & $130-800 \mathrm{~nm}$ \\
Entrance slit width & 15 microns \\
Resolution (FWHM) & $0.01 \mathrm{~nm}$ from $130-450 \mathrm{~nm}$ \\
& $0.02 \mathrm{~nm}$ from $450-800 \mathrm{~nm}$ \\
Thermal regulation & Controlled to $30 \pm 1{ }^{\circ} \mathrm{C}$ \\
Frequency & $27.12 \mathrm{MHz}$ \\
Pump & Dual channel peristaltic pump (12 roller) \\
Detector & Linear arrays of CCD (3648 pixels/array) \\
Nebulizer & Cross-flow nebulizer \\
ICP-torch & Demountable, radial viewing \\
\hline Operating Conditions & \\
\hline Coolant flow & $13 \mathrm{~L} / \mathrm{min}$ \\
Auxiliary flow & $0.8 \mathrm{~L} / \mathrm{min}$ \\
Nebulizer gas flow & $0.8 \mathrm{~L} / \mathrm{min}$ \\
Total time of measurement & $28 \mathrm{~s}$ \\
Pump speed & $30 \mathrm{rpm}$ \\
Nebulizer pressure & $3 \mathrm{bars}$ \\
Pressure on manometer & $6 \mathrm{bars}$ \\
RF power out put & $1.2 \mathrm{~kW}$ \\
Reflected power & $<10 \mathrm{~W}$ \\
Input power & $230 \mathrm{~V}$ AC \\
\hline & \\
\hline
\end{tabular}




\section{Atomic Mpectroscopy \\ 1 Vol. 36(1), Jan./Feb. 2015}

interfered analytical lines were identified along with evaluation of the correction factor. The tolerance levels of Gd on these lines were also studied. The analytical performance such as detection limits, sensitivity, and linear dynamic range were studied for all of the analytical lines. Since the correction factor arising due to the spectral interference of $\mathrm{Gd}$ is a function of Gd concentration, an ICP-AES-based method was developed for the simultaneous determination of $\mathrm{Gd}$ along with the analytes. Based on the spectral interference of Gd as well as the analytical performance, an ICP-AESbased method was developed for the determination of these analytes at trace levels without any separation in the Gd matrix and validated by using synthetic samples prepared from commercially available standard reference materials.

\section{RESULTS AND DISCUSSION}

\section{Determination of Gd by ICP-AES}

Though Gd exhibits line-rich emission spectra, four lines of $\mathrm{Gd}$ (335.047 nm, $335.862 \mathrm{~nm}, 336.223$ $\mathrm{nm}$, and $342.247 \mathrm{~nm}$ ) were chosen to establish the calibration curves and to study the analytical performance (see Figure 2). It was found that these four lines can be used for the determination of Gd with less than 5\% RSD (Table II). The sensitivity and detection limits of Gd with these analytical lines were evaluated using the slopes of the calibration curves and the concentration equivalent to the intensity equal to the average of the blank value + three times the standard deviation of the above measurements, i.e., $\mathbf{x}+3 \sigma$. The description of the linear dynamic range for each line of Gd is listed in Table II. The sensitivity of these lines follows the order $335.047 \mathrm{~nm}<335.862$ $\mathrm{nm}<336.223 \mathrm{~nm}<342.247 \mathrm{~nm}$, respectively, while the order for the detection limit is $335.047 \mathrm{~nm}$ $<342.247 \mathrm{~nm}<336.223 \mathrm{~nm}<$ 335.862 nm (see Table II).

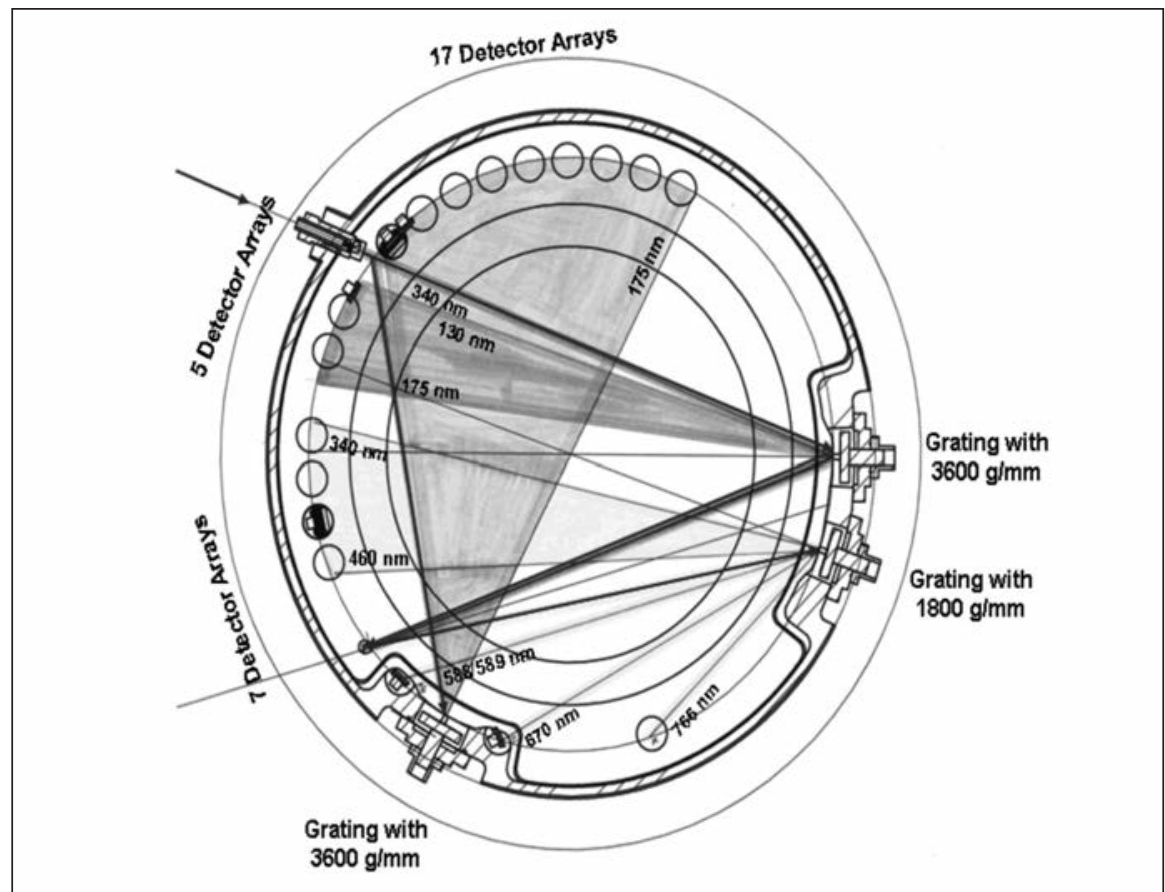

Fig. 1: Cross-sectional view of array of CCD-based detector.

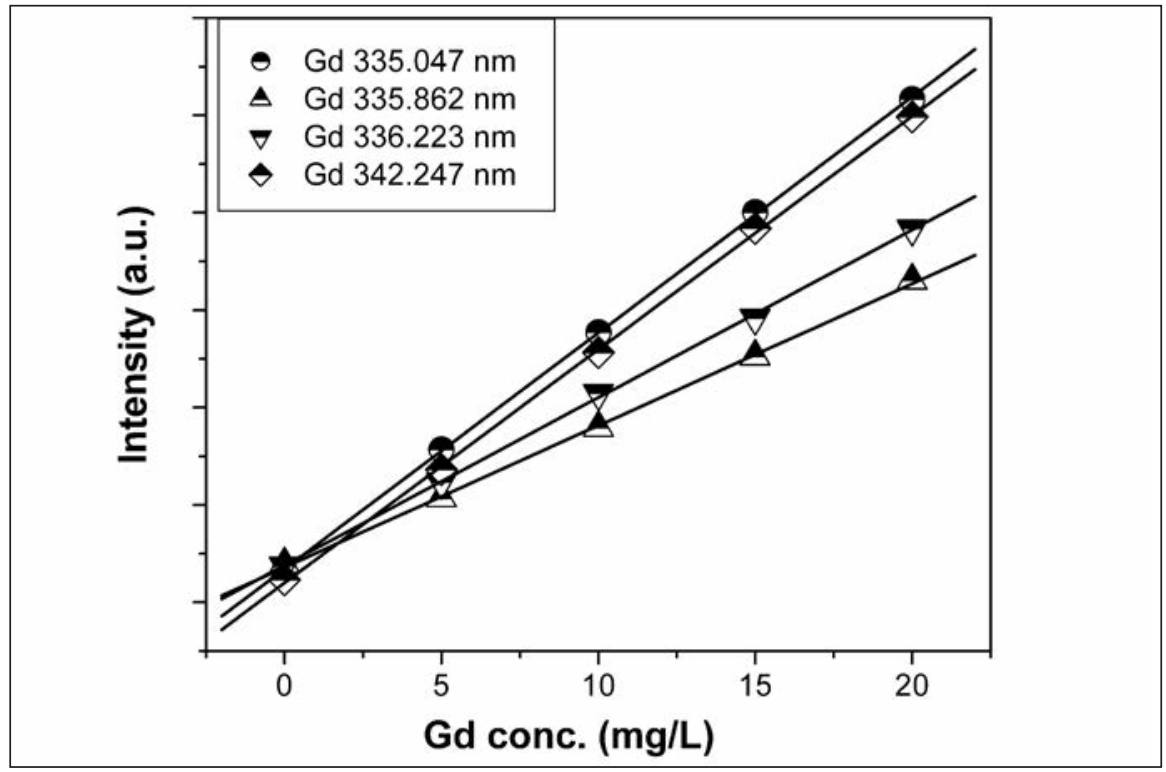

Fig. 2: Calibration curves for different analytical lines of $G d$. 
TABLE II

Determination of Gd by ICP-AES Using Different Analytical Lines

\begin{tabular}{ccccc}
\hline $\begin{array}{c}\mathrm{Gd} \\
(\mathrm{mg} / \mathrm{L})\end{array}$ & $\begin{array}{c}335.047 \mathrm{~nm} \\
(\mathrm{mg} / \mathrm{L})\end{array}$ & $\begin{array}{c}335.862 \mathrm{~nm} \\
(\mathrm{mg} / \mathrm{L})\end{array}$ & $\begin{array}{c}336.223 \mathrm{~nm} \\
(\mathrm{mg} / \mathrm{L})\end{array}$ & $\begin{array}{c}342.247 \mathrm{~nm} \\
(\mathrm{mg} / \mathrm{L})\end{array}$ \\
\hline 1 & $0.90 \pm 0.02$ & $0.95 \pm 0.04$ & $0.93 \pm 0.07$ & $0.90 \pm 0.04$ \\
5 & $5.3 \pm 0.3$ & $4.8 \pm 0.4$ & $5.1 \pm 0.4$ & $4.9 \pm 0.2$ \\
10 & $9.8 \pm 0.8$ & $9.9 \pm 0.3$ & $9.7 \pm 0.4$ & $9.9 \pm 0.5$ \\
50 & $51.8 \pm 1.1$ & $49.3 \pm 1.0$ & $50.5 \pm 1.0$ & $50.2 \pm 0.8$ \\
100 & $98.5 \pm 2.5$ & $102.1 \pm 1.9$ & $100.3 \pm 1.6$ & $101.6 \pm 1.5$ \\
500 & $497 \pm 2$ & $499 \pm 3$ & $498 \pm 2$ & $502 \pm 3$ \\
1000 & $1000 \pm 3$ & $999 \pm 3$ & $995 \pm 6$ & $1001 \pm 6$ \\
\hline D.L. (mg/L) & 0.029 & 0.057 & 0.056 & 0.032 \\
\hline $\begin{array}{l}\text { Sensitivity } \\
(\text { counts/mg/L) }\end{array}$ & $10.3 \times 10^{4}$ & $6.6 \times 10^{4}$ & $7.6 \times 10^{4}$ & $9.9 \times 10^{4}$ \\
\hline $\begin{array}{l}\text { Linear Dynamic } \\
\text { range }(\mathrm{mg} / \mathrm{L})\end{array}$ & $0.02-1000$ & $0.057-1000$ & $0.056-1000$ & $0.032-1000$ \\
\hline \% RSD & $\sim 1 \%$ & $\sim 4 \%$ & $\sim 3 \%$ & $\sim 2 \%$ \\
\hline
\end{tabular}

\section{Spectral Interference of Gd on Different Analytes}

The ground state electronic configuration for $\mathrm{Gd}$ is $[\mathrm{Xe}] \cdot 4 \mathrm{f}^{7} .5 \mathrm{~d}^{1} \cdot 6 \mathrm{~s}^{2}$ with the ground state term symbol of ${ }^{9} \mathrm{D}_{2}$. Due to the various possible transitions in $\mathrm{Gd}$, it interferes in the spectra of other analytes making their determination erroneous, especially when the analytes are present in a Gd matrix at trace levels.

$\mathrm{Ag}, \mathrm{Ba}, \mathrm{Bi}, \mathrm{Cd}, \mathrm{Cr}, \mathrm{Cu}, \mathrm{Dy}, \mathrm{Li}, \mathrm{Lu}$, Mg, Mn, Na, Nd, Sr, Zn.

The spectral interference of $\mathrm{Gd}$ on the determination of $\mathrm{Ag}, \mathrm{Ba}, \mathrm{Bi}$, $\mathrm{Cd}, \mathrm{Cr}, \mathrm{Cu}, \mathrm{Dy}, \mathrm{Li}, \mathrm{Lu}, \mathrm{Mg}, \mathrm{Mn}, \mathrm{Na}$, $\mathrm{Nd}, \mathrm{Sr}$, and $\mathrm{Zn}$ was studied as a function of Gd concentration. It was observed that the interference is linear with a $\mathrm{Gd}$ concentration. The spectral interference of $\mathrm{Gd}$ on these analytes is listed in Table III, while the analytical performance of these lines is summarized in Table IV.

\section{Silver (Ag)}

Four analytical lines of Ag were chosen for the present purpose: $338.289 \mathrm{~nm}, 328.068 \mathrm{~nm}, 224.641$ $\mathrm{nm}$, and $243.779 \mathrm{~nm}$. The 224.641 $\mathrm{nm}$ line was found to be enormously interfered by Gd and is therefore not recommended for the direct determination of $\mathrm{Ag}$ in a Gd matrix. Practically no interference from Gd was observed for Ag at $328.068 \mathrm{~nm}$ with a $1000 \mathrm{mg} / \mathrm{L}$ tolerance level. The Gd tolerance levels for the $338.289 \mathrm{~nm}, 224.641 \mathrm{~nm}$, and $243.779 \mathrm{~nm}$ analytical lines of $\mathrm{Ag}$ are $100 \mathrm{mg} / \mathrm{L}, 50 \mathrm{mg} / \mathrm{L}$, and $50 \mathrm{mg} / \mathrm{L}$, respectively. The analytical performance for $328.068 \mathrm{~nm}$ was 0.011 $\mathrm{mg} / \mathrm{L}$ (detection limit) and 1359 counts/mg/L (sensitivity). Based on both of these factors, Ag at 328.068 $\mathrm{nm}$ was chosen as the best line for Ag determination in a Gd matrix.

\section{Barium (Ba)}

Three different analytical lines of $\mathrm{Ba}(230.424 \mathrm{~nm}, 233.527 \mathrm{~nm}$, and $455.404 \mathrm{~nm}$ ) were investigated. The contribution due to the spec- tral interference of Gd for these lines followed the trend 455.404 $\mathrm{nm}<230.424 \mathrm{~nm}<233.527 \mathrm{~nm}$. For $\mathrm{Ba}$, the least interfered line of $455.404 \mathrm{~nm}$ showed the best analytical performance (detection limit $0.027 \mathrm{mg} / \mathrm{L}$, sensitivity 2900.1 counts/mg/L), and hence should be the ideal choice for Ba estimation in the presence of a Gd matrix.

\section{Bismuth (Bi)}

Of the five analytical lines of $\mathrm{Bi}$ chosen for the present study (190.241 nm, $206.170 \mathrm{~nm}, 222.825$ $\mathrm{nm}, 223.061 \mathrm{~nm}$, and $306.772 \mathrm{~nm}$ ), the $222.825 \mathrm{~nm}, 190.241 \mathrm{~nm}$, and 206.170 nm lines showed significant interference from Gd and were not considered for further studies. The detection limit of the remaining two lines follows the order of $223.061 \mathrm{~nm}<306.772 \mathrm{~nm}$ and the sensitivities are 263.7 counts/mg/L and 1117.95 counts/ $\mathrm{mg} / \mathrm{L}$, respectively. Thus, for Bi the $306.772 \mathrm{~nm}$ line was chosen.

\section{Cadmium (Cd)}

Of the four lines for Cd (214.438 $\mathrm{nm}, 226.502 \mathrm{~nm}, 228.802 \mathrm{~nm}$, and $361.051 \mathrm{~nm}$ ), the $361.051 \mathrm{~nm}$ line was highly interfered by $\mathrm{Gd}$, while the $214.438 \mathrm{~nm}$ and $228.802 \mathrm{~nm}$ lines showed moderate interference. The $226.502 \mathrm{~nm}$ line (tolerance level, $1000 \mathrm{mg} / \mathrm{L}$ ) and the 214.438 $\mathrm{nm}$ line (tolerance level, $500 \mathrm{mg} / \mathrm{L}$ ) have comparable detection limits of $0.0069 \mathrm{mg} / \mathrm{L}$ and $0.007 \mathrm{mg} / \mathrm{L}$, respectively. The sensitivities of these lines are 8971.8 counts/mg/L and 4083.7 counts/ mg/L, respectively. Thus, the best line which can serve our purpose is $226.502 \mathrm{~nm}$.

\section{Chromium (Cr)}

Among the five lines of $\mathrm{Cr}$ (205.618 nm, 267.716 nm, 283.563 $\mathrm{nm}, 284.325 \mathrm{~nm}$, and $284.984 \mathrm{~nm}$ ), the $205.618 \mathrm{~nm}$ line showed no spectral interference from $\mathrm{Gd}$ up to a tolerance level of $1000 \mathrm{mg} / \mathrm{L}$. This line also gives the best analytical performance, with a detection limit 


\section{Atomic Apectroscopy \\ $\bigcup$ Vol. 36(1), Jan./Feb. 2015}

TABLE III

Spectral Interference of Gd on Ag, Ba, Bi, Cd, Cr, Cu, Dy, Li, Lu, Mg, Mn, Na, Nd, Sr, and Zn Analytes

\begin{tabular}{|c|c|c|c|c|c|c|c|c|c|}
\hline Element & $\begin{array}{l}\text { Analytical } \\
\text { Lines } \\
(\mathrm{nm})\end{array}$ & $\begin{array}{c}\text { Contribution } \\
\text { from } \\
1000 \mathrm{mg} / \mathrm{L} \\
\text { of } \mathrm{Gd}\end{array}$ & $\begin{array}{l}\text { Correction } \\
\text { Factor }\end{array}$ & $\begin{array}{l}\text { Tolerance } \\
\text { Level } \\
(\mathrm{mg} / \mathrm{L})\end{array}$ & Element & $\begin{array}{l}\text { Analytical } \\
\text { Lines } \\
\text { (nm) }\end{array}$ & $\begin{array}{c}\text { Contribution } \\
\text { from } \\
1000 \mathrm{mg} / \mathrm{L} \\
\text { of } \mathrm{Gd}\end{array}$ & $\begin{array}{l}\text { Correction } \\
\text { Factor }\end{array}$ & $\begin{array}{c}\text { Tolerance } \\
\text { Level } \\
\text { (mg/L) }\end{array}$ \\
\hline \multirow[t]{4}{*}{$\mathrm{Ag}$} & 338.289 & 0.45 & $4 \times 10^{-4}$ & 100 & \multirow[t]{5}{*}{$\mathrm{Mg}$} & 279.553 & 0.02 & $2 \times 10^{-5}$ & 1000 \\
\hline & 328.068 & 0.04 & 0 & 1000 & & 280.270 & 0.02 & $2 \times 10^{-5}$ & 1000 \\
\hline & 224.641 & 12.59 & $1.3 \times 10^{-2}$ & 50 & & 285.213 & 0.07 & $7 \times 10^{-5}$ & 500 \\
\hline & 243.779 & 2.1 & $2 \times 10^{-3}$ & 50 & & 279.079 & 2.26 & $2.2 \times 10^{-3}$ & 50 \\
\hline \multirow[t]{3}{*}{$\mathrm{Ba}$} & 455.404 & $*$ & - & 1000 & & 202.647 & 1.29 & $1.3 \times 10^{-3}$ & 5 \\
\hline & 233.527 & 1.71 & $2 \times 10^{-3}$ & 50 & \multirow[t]{2}{*}{$\mathrm{Mn}$} & 257.611 & 0.04 & $4 \times 10^{-5}$ & 1000 \\
\hline & 230.424 & 0.49 & $5 \times 10^{-4}$ & 100 & & 259.373 & 0.03 & $3 \times 10^{-5}$ & 1000 \\
\hline \multirow[t]{5}{*}{$\mathrm{Bi}$} & 223.051 & 1.47 & $2 \times 10^{-3}$ & 50 & & 260.569 & 0.09 & $9 \times 10^{-5}$ & 500 \\
\hline & 190.241 & 7.46 & $8 \times 10^{-3}$ & 100 & & 294.921 & $*$ & - & 1000 \\
\hline & 306.772 & $*$ & - & 1000 & & 403.076 & 1.69 & $1.7 \times 10^{-3}$ & 50 \\
\hline & 222.825 & \# & Rejected & 5 & $\mathrm{Na}$ & 589.592 & 0.06 & $1 \times 10^{-4}$ & 1000 \\
\hline & 206.170 & 3.62 & $4 \times 10^{-3}$ & 50 & & 588.995 & 0.17 & $2 \times 10^{-4}$ & 0.05 \\
\hline \multirow[t]{4}{*}{$\mathrm{Cd}$} & 214.438 & 0.1 & $1 \times 10^{-4}$ & 500 & & 330.237 & 12.64 & $1.2 \times 10^{-2}$ & 50 \\
\hline & 226.502 & 0.02 & 0 & 1000 & & 330.298 & \# & Rejected & 50 \\
\hline & 228.802 & 0.49 & $5 \times 10^{-4}$ & 50 & $\mathrm{Nd}$ & 401.225 & $*$ & - & 1000 \\
\hline & 361.051 & $\#$ & Rejected & 50 & & 430.358 & 0.85 & $9 \times 10^{-4}$ & 100 \\
\hline \multirow[t]{5}{*}{$\mathrm{Cr}$} & 267.716 & 0.42 & $4 \times 10^{-4}$ & 50 & & 406.109 & 15.82 & $1.6 \times 10^{-2}$ & 5 \\
\hline & 205.618 & 0.03 & 0 & 1000 & & 417.731 & 0.49 & $5 \times 10-4$ & 500 \\
\hline & 283.563 & 0.16 & $2 \times 10^{-4}$ & 500 & $\mathrm{Zn}$ & 213.856 & 0.04 & 0 & 1000 \\
\hline & 284.325 & $*$ & - & 1000 & & 206.200 & 2.05 & $2.1 \times 10^{-3}$ & 50 \\
\hline & 284.984 & 1.32 & $1 \times 10^{-3}$ & 50 & & 202.613 & 0.17 & $2 \times 10^{-4}$ & 50 \\
\hline \multirow[t]{3}{*}{$\mathrm{Sr}$} & 407.771 & 0.01 & 0 & 1000 & & 334.502 & 3.96 & $4 \times 10^{-3}$ & 200 \\
\hline & 421.553 & 0.03 & 0 & 1000 & $\mathrm{Lu}$ & 219.554 & 0.554 & $5.5 \times 10^{-4}$ & 50 \\
\hline & 460.733 & 0.15 & $1 \times 10^{-4}$ & 100 & & 261.542 & 0.037 & $3.7 \times 10^{-5}$ & 1000 \\
\hline \multirow[t]{5}{*}{ Dy } & 353.170 & 0.06 & $1 \times 10^{-4}$ & 1000 & & 291.139 & 0.151 & $1.5 \times 10^{-4}$ & 200 \\
\hline & 394.468 & $*$ & - & 1000 & & 307.760 & 0.63 & $6.3 \times 10^{-4}$ & 50 \\
\hline & 340.780 & 4.87 & $5 \times 10^{-3}$ & 5 & $\mathrm{Cu}$ & 324.754 & 0.03 & 0 & 1000 \\
\hline & 353.602 & 0.37 & $4 \times 10^{-4}$ & 100 & & 327.396 & 0.11 & $1 \times 10^{-4}$ & 200 \\
\hline & 364.540 & 9.99 & $1 \times 10^{-2}$ & 5 & & 224.700 & 0.68 & $7 \times 10^{-4}$ & 50 \\
\hline \multirow[t]{4}{*}{$\mathrm{Li}$} & 670.780 & $*$ & - & 1000 & & 219.226 & 3.21 & $3.2 \times 10^{-3}$ & 50 \\
\hline & 460.289 & $\#$ & Rejected & 50 & & 219.958 & 1.15 & $1.2 \times 10^{-3}$ & 0.5 \\
\hline & 323.261 & $\#$ & Rejected & 5 & & & & & \\
\hline & 274.118 & 18.77 & $1.9 \times 10^{-2}$ & 50 & & & & & \\
\hline
\end{tabular}

Note: * No interference, \# significant interference. 
TABLE IV

Analytical Performance of Ag, Ba, Bi, Cd, Cr, Cu, Dy, Li, Lu, Mg, Mn, $\mathrm{Na}, \mathrm{Nd}, \mathrm{Sr}$, and $\mathrm{Zn}$ Analytes in the Presence of Gd

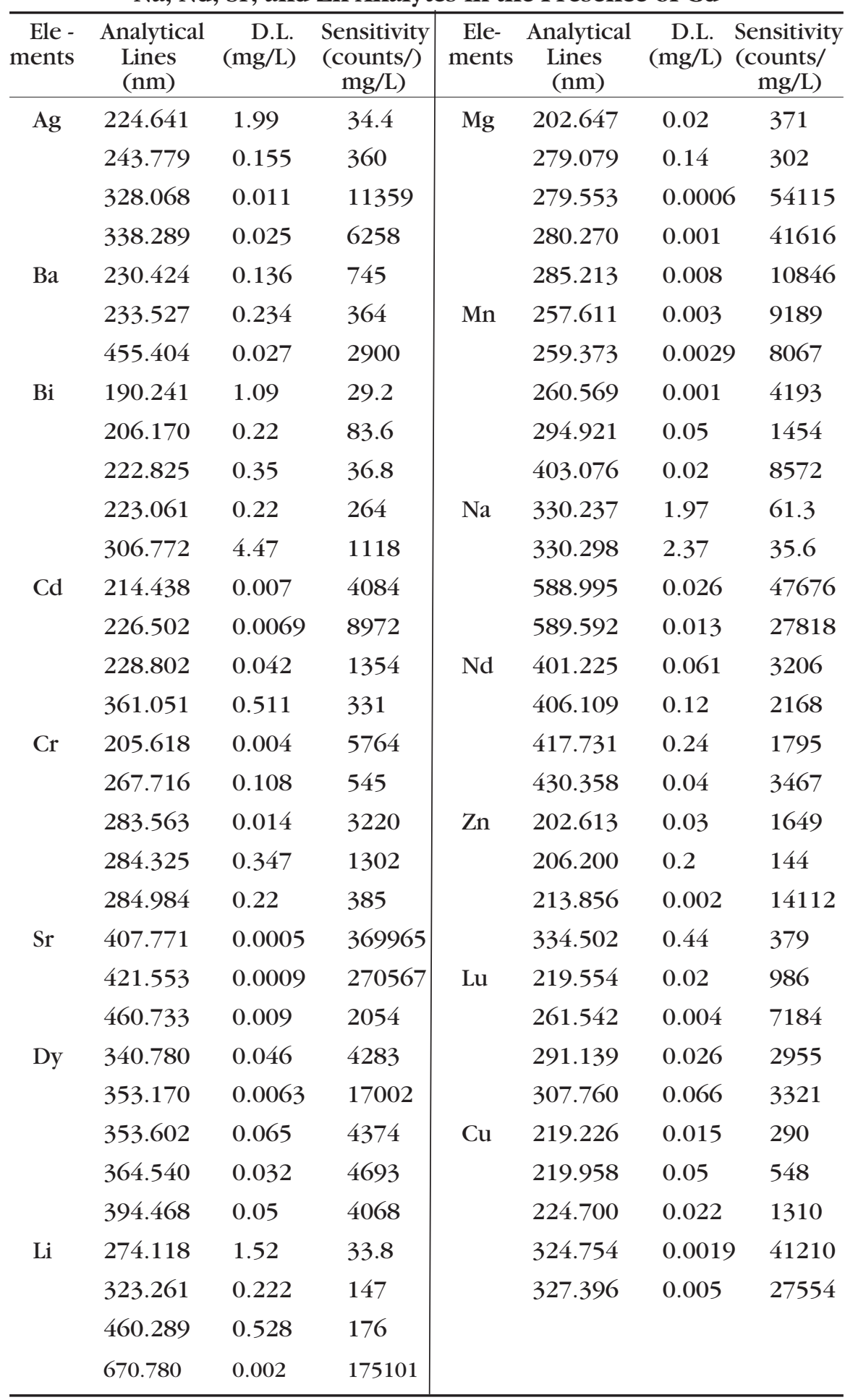

of $0.004 \mathrm{mg} / \mathrm{L}$ and a sensitivity of $5764.5 \mathrm{mg} / \mathrm{L}$. Hence, this line was chosen for further study.

\section{Copper (Cu)}

Out of five analytical lines for $\mathrm{Cu}$ (219.226 nm, $219.958 \mathrm{~nm}, 224.700$ $\mathrm{nm}, 324.754 \mathrm{~nm}$, and $327.396 \mathrm{~nm}$ ), the $324.754 \mathrm{~nm}$ line showed the best analytical performance with no spectral interference from $\mathrm{Gd}$. Thus, the $324.754 \mathrm{~nm}$ line should be the best choice for the present study.

\section{Dysprosium (Dy)}

On the basis of analytical performance, both the $394.468 \mathrm{~nm}$ and $353.602 \mathrm{~nm}$ lines appeared to be good, but they showed significant spectral interference. Fortunately for Dy, the best performing analytical line is $353.170 \mathrm{~nm}$ which shows the least spectral interference.

\section{Lithium (Li)}

Among the chosen lines of $\mathrm{Li}$ (274.118 nm, $323.261 \mathrm{~nm}, 460.289$ $\mathrm{nm}$, and $670.780 \mathrm{~nm}$ ), the only line which is not interfered by a Gd matrix is $670.780 \mathrm{~nm}$, having a tolerance level of $1000 \mathrm{mg} / \mathrm{L}$. The analytical performance (detection limit $0.002 \mathrm{mg} / \mathrm{L}$, and sensitivity 175101.25 counts/mg/L), making it the best possible line for analysis.

\section{Lutetium (Lu)}

Among four lines of Lu (219.554 $\mathrm{nm}, 261.542 \mathrm{~nm}, 291.139 \mathrm{~nm}$, and $307.760 \mathrm{~nm}$ ), the $261.542 \mathrm{~nm}$ line showed practically no interference from $1000 \mathrm{mg} / \mathrm{L}$ of $\mathrm{Gd}$. The $261.542 \mathrm{~nm}$ Lu line has lowest detection limit, while the other three lines have almost comparable detection limits. The sensitivity followed the trend $261.542 \mathrm{~nm}>$ $307.760 \mathrm{~nm}>291.139 \mathrm{~nm}>$ $219.554 \mathrm{~nm}$. Thus, the $261.542 \mathrm{~nm}$ line has best performance, shows no spectral interference, and should be the best choice of determining $\mathrm{Lu}$ in the presence of $\mathrm{Gd}$ even at trace levels. 


\section{Magnesium (Mg)}

Out of five analytical lines of $\mathrm{Mg}$ (279.553 nm, $280.270 \mathrm{~nm}, 285.213$ $\mathrm{nm}, 279.079 \mathrm{~nm}$, and $202.647 \mathrm{~nm}$ ), the $279.079 \mathrm{~nm}$ and $202.647 \mathrm{~nm}$ lines were found to suffer from severe spectral interference from Gd. No interference was observed from Gd up to $1000 \mathrm{mg} / \mathrm{L}$ for the analytical lines of $280.270 \mathrm{~nm}$, $297.553 \mathrm{~nm}$, and $285.213 \mathrm{~nm}$. The detection limit values followed the trend $279.553<280.270 \mathrm{~nm}$ $<285.213 \mathrm{~nm}<202.647 \mathrm{~nm}$ $<279.079 \mathrm{~nm}$, while the trend was completely reversed for sensitivity. In view of spectral interference as well as analytical performance, the $\mathrm{Mg} 279.553 \mathrm{~nm}$ line was thought to be the best choice in the presence of Gd with a detection limit of $0.0006 \mathrm{mg} / \mathrm{L}$ and a sensitivity of 54115.05 counts/mg/L.

\section{Manganese (Mn)}

Of the five different analytical lines of Mn (257.611 nm, 259.373 $\mathrm{nm}, 260.569 \mathrm{~nm}, 294.921 \mathrm{~nm}$, and $403.076 \mathrm{~nm})$, the $403.076 \mathrm{~nm}$ line was interfered by Gd and hence was not taken into account. There was practically no interference observed from Gd on the 257.611 $\mathrm{nm}$ line up to $1000 \mathrm{mg} / \mathrm{L}$. The sensitivity for the remaining four lines follows the order $257.611 \mathrm{~nm}>$ $259.373 \mathrm{~nm}>260.569 \mathrm{~nm}>$ $294.921 \mathrm{~nm}$, with a detection limit of $0.003 \mathrm{mg} / \mathrm{L}, 0.0029 \mathrm{mg} / \mathrm{L}, 0.001$ $\mathrm{mg} / \mathrm{L}$ and $0.05 \mathrm{mg} / \mathrm{L}$, respectively. Thus the $257.611 \mathrm{~nm}$ line should be the better choice for the present investigation.

\section{Sodium (Na)}

Among four lines of $\mathrm{Na}$ (330.237 $\mathrm{nm}, 330.298 \mathrm{~nm}, 589.592 \mathrm{~nm}$, and $588.995 \mathrm{~nm}$ ), the $330.237 \mathrm{~nm}$ and $330.298 \mathrm{~nm}$ lines were highly interfered by Gd and hence were not chosen for further studies. Of the remaining two lines, only 589.592 $\mathrm{nm}$ was found to be unaffected by Gd. Furthermore, the analytical performance of this line was found to be superior to the rest and was thus considered the best choice for the present study.

\section{Neodymium (Nd)}

Of the four lines of $\mathrm{Nd}(401.225$ $\mathrm{nm}, 406.109 \mathrm{~nm}, 417.731 \mathrm{~nm}$, and $430.358 \mathrm{~nm})$, the $401.225 \mathrm{~nm}$ and $430.358 \mathrm{~nm}$ lines have almost comparable analytical performance (detection limit and sensitivity). However, the $401.225 \mathrm{~nm}$ line shows no spectral interference from Gd and was considered to be the ideal line for trace level determination of $\mathrm{Nd}$ in a $\mathrm{Gd}$ matrix.

\section{Strontium (Sr)}

Of three analytical lines for $\mathrm{Sr}$ ( $407.771 \mathrm{~nm}, 421.553 \mathrm{~nm}$, and $460.733 \mathrm{~nm}$ ), the $460.733 \mathrm{~nm}$ line was found to be significantly interfered by Gd, while the other two lines were free of spectral interference. The $407.771 \mathrm{~nm}$ line showed slightly better analytical performance (detection limit $0.0005 \mathrm{mg} / \mathrm{L}$ and sensitivity 369964.95 counts/ $\mathrm{mg} / \mathrm{L}$ ) compared to the $421.553 \mathrm{~nm}$ line (detection limit $0.0009 \mathrm{mg} / \mathrm{L}$ and sensitivity 270567.2 counts/ $\mathrm{mg} / \mathrm{L}$ ), and was thus considered the best choice for $\mathrm{Sr}$ determination in the presence of Gd.

\section{Zinc (Zn)}

Four different analytical lines for $\mathrm{Zn}(202.613 \mathrm{~nm}, 206.200 \mathrm{~nm}$, $213.856 \mathrm{~nm}$, and $334.502 \mathrm{~nm}$ ) were chosen in the present study. The only line which is not interfered by Gd was $213.856 \mathrm{~nm}$, with a tolerance level of $1000 \mathrm{mg} / \mathrm{L}$ of $\mathrm{Gd}$ and the lowest detection limit. The sensitivity of the lines followed the trend $213.856 \mathrm{~nm}>202.613 \mathrm{~nm}$ $>334.502 \mathrm{~nm}>206.220 \mathrm{~nm}$. The analytical performance and interference results revealed that the $\mathrm{Zn}$ $213.856 \mathrm{~nm}$ line is the best for the determination in a Gd matrix.

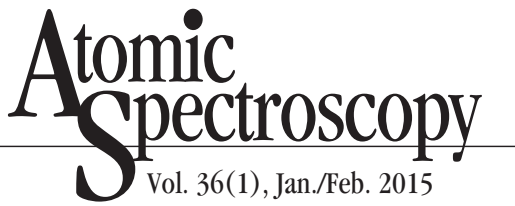

Ca, B, Co, Fe, Ga, La, Ni, Pr, T1, $\mathrm{Ce}, \mathrm{Pb}, \mathrm{Al}$, and In

The results of the spectral interference study for these analytes are summarized in Table $\mathrm{V}$ and the analytical performance results in Table VI.

\section{Calcium (Ca)}

For Ca, five lines $(183.801 \mathrm{~nm}$, $315.887 \mathrm{~nm}, 317.933 \mathrm{~nm}, 393.366$ $\mathrm{nm}$, and $396.847 \mathrm{~nm}$ ) were under investigation. The $183.801 \mathrm{~nm}$ and $315.887 \mathrm{~nm}$ lines showed interference from Gd, and were not suitable for trace determination of $\mathrm{Ca}$ in the presence of a Gd matrix. The $393.366 \mathrm{~nm}$ line showed moderate spectral interference from Gd, while the analytical performance was found to have the lowest detection limit $(0.0009 \mathrm{mg} / \mathrm{L})$ and the highest sensitivity (586501.5 counts/mg/L). Thus, Ca at the $393.366 \mathrm{~nm}$ line was found to be best for its trace level determination in the presence of large amounts of Gd.

\section{Boron (B)}

For $\mathrm{B}$, five analytical lines (136.246 nm, $182.641 \mathrm{~nm}, 208.959$ $\mathrm{nm}, 249.677 \mathrm{~nm}$, and $249.773 \mathrm{~nm}$ ) were chosen to study the spectral interference of Gd. The 136.246 nm line showed a significant contribution from Gd. The correction factors due to the spectral interference of Gd for the other analytical lines of $B$ follow the trend: $208.959 \mathrm{~nm}<182.641 \mathrm{~nm}$ $<249.773 \mathrm{~nm}<249.677 \mathrm{~nm}$. The detection limits of the analytical lines follow the order: $208.959 \mathrm{~nm}$ $(0.019 \mathrm{mg} / \mathrm{L})<249.773 \mathrm{~nm}(0.024$ $\mathrm{mg} / \mathrm{L})<182.641 \mathrm{~nm}(0.032 \mathrm{mg} / \mathrm{L})$ $<249.677 \mathrm{~nm}(0.054 \mathrm{mg} / \mathrm{L})$ $<136.246 \mathrm{~nm}(14.57 \mathrm{mg} / \mathrm{L})$. The sensitivity of these lines followed the trend: $208.959 \mathrm{~nm}$ $>249.773 \mathrm{~nm}>249.677 \mathrm{~nm}$ $>182.641 \mathrm{~nm}>136.246 \mathrm{~nm}$. Considering all of these facts, $\mathrm{B}$ at the $208.959 \mathrm{~nm}$ line was believed to be the best choice. 
TABLE V

Spectral Interference of Gd on $\mathrm{Ca}, \mathrm{B}, \mathrm{Co}, \mathrm{Fe}, \mathrm{Ga}, \mathrm{La}, \mathrm{Ni}, \mathrm{Pr}, \mathrm{Tl}, \mathrm{Ce}, \mathrm{Pb}, \mathrm{Al}$ and In Analytes

\begin{tabular}{|c|c|c|c|c|c|c|c|c|c|}
\hline Element & $\begin{array}{c}\text { Analytical } \\
\text { Lines } \\
\text { (nm) }\end{array}$ & $\begin{array}{l}\text { Contribution } \\
\text { from } \\
1000 \mathrm{mg} / \mathrm{L} \\
\text { of } \mathrm{Gd}\end{array}$ & $\begin{array}{l}\text { Correction } \\
\text { Factor }\end{array}$ & $\begin{array}{c}\text { Tolerance } \\
\text { Level } \\
(\mathrm{mg} / \mathrm{L})\end{array}$ & Element & $\begin{array}{c}\text { Analytical } \\
\text { Lines } \\
(\mathrm{nm})\end{array}$ & $\begin{array}{c}\text { Contribution } \\
\text { from } \\
1000 \mathrm{mg} / \mathrm{L} \\
\text { of } \mathrm{Gd}\end{array}$ & $\begin{array}{l}\text { Correction } \\
\text { Factor }\end{array}$ & $\begin{array}{c}\text { Tolerance } \\
\text { Level } \\
(\mathrm{mg} / \mathrm{L})\end{array}$ \\
\hline \multirow[t]{6}{*}{$\mathrm{Ca}$} & 396.847 & 0.23 & $2 \times 10^{-4}$ & 5 & \multirow[t]{4}{*}{$\operatorname{Pr}$} & 411.846 & 0.28 & $3 \times 10^{-4}$ & 200 \\
\hline & 393.366 & 0.24 & $2 \times 10^{-4}$ & 5 & & 417.939 & 0.44 & $4 \times 10^{-4}$ & 500 \\
\hline & 317.933 & 0.67 & $7 \times 10^{-4}$ & 50 & & 422.535 & 4.98 & $5 \times 10^{-3}$ & 50 \\
\hline & 315.887 & 2.22 & $2.2 \times 10^{-3}$ & 500 & & 414.311 & $*$ & - & 1000 \\
\hline & 183.801 & 8.43 & $8.4 \times 10^{-3}$ & 50 & \multirow[t]{2}{*}{$\mathrm{Tl}$} & 190.864 & 0.32 & $3 \times 10^{-4}$ & 50 \\
\hline & 422.673 & 0.28 & $3 \times 10^{-4}$ & 100 & & 276.787 & $\#$ & Rejected & 50 \\
\hline \multirow[t]{5}{*}{ B } & 249.773 & 0.76 & $8 \times 10^{-4}$ & 0.05 & \multirow[t]{5}{*}{ Cs } & 418.660 & 0.72 & $7 \times 10^{-4}$ & 200 \\
\hline & 249.677 & 3.03 & $3 \times 10^{-3}$ & 0.05 & & 448.691 & \# & Rejected & 50 \\
\hline & 182.641 & 0.28 & $3 \times 10^{-4}$ & 0.05 & & 413.765 & 1.36 & $1.4 \times 10^{-3}$ & 100 \\
\hline & 208.959 & 0.08 & $1 \times 10^{-4}$ & 0.05 & & 413.380 & 0.81 & $8 \times 10^{-4}$ & 200 \\
\hline & 136.246 & $\#$ & Rejected & & & 393.373 & 17.11 & $1.7 \times 10^{-2}$ & 0.05 \\
\hline \multirow[t]{4}{*}{ Co } & 228.616 & 0.56 & $6 \times 10^{-4}$ & 50 & \multirow[t]{4}{*}{$\mathrm{Pb}$} & 220.353 & 4.76 & $4.8 \times 10^{-3}$ & 50 \\
\hline & 238.892 & 0.23 & $2 \times 10^{-4}$ & 100 & & 405.778 & 4.19 & $4.2 \times 10^{-3}$ & 200 \\
\hline & 230.786 & 1.1 & $1.1 \times 10^{-3}$ & 50 & & 283.305 & 5.8 & $5.8 \times 10^{-3}$ & 50 \\
\hline & 237.862 & 0.45 & $4 \times 10^{-4}$ & 50 & & 261.418 & 19.06 & $1.9 \times 10^{-2}$ & 50 \\
\hline \multirow[t]{10}{*}{$\mathrm{Fe}$} & 259.941 & 0.24 & $2 \times 10^{-4}$ & 50 & \multirow[t]{5}{*}{ Al } & 167.078 & \# & Rejected & \\
\hline & 238.204 & 1.37 & $1.4 \times 10^{-3}$ & 50 & & 396.152 & 0.1 & $1 \times 10^{-4}$ & 200 \\
\hline & 239.562 & 0.18 & $2 \times 10^{-4}$ & 50 & & 394.401 & 4.22 & $4.2 \times 10^{-3}$ & 5 \\
\hline & 244.451 & 3.12 & $3.1 \times 10^{-3}$ & 50 & & 308.215 & $\#$ & Rejected & 5 \\
\hline & 261.187 & 0.51 & $5 \times 10^{-4}$ & 50 & & 309.271 & * & - & 1000 \\
\hline & 262.567 & 3.56 & $3.6 \times 10^{-3}$ & 50 & \multirow[t]{4}{*}{ In } & 230.606 & 0.68 & $7 \times 10^{-4}$ & 100 \\
\hline & 262.829 & 2.62 & $2.6 \times 10^{-3}$ & 100 & & 325.609 & 2.35 & $2.4 \times 10^{-3}$ & 50 \\
\hline & 275.573 & 0.86 & $9 \times 10^{-4}$ & 50 & & 451.131 & $*$ & - & 1000 \\
\hline & 241.331 & 6.48 & $6.5 \times 10^{-3}$ & 50 & & 303.936 & 1.88 & $1.9 \times 10^{-3}$ & 50 \\
\hline & 373.486 & 0.49 & $5 \times 10^{-4}$ & 200 & \multirow[t]{7}{*}{$\mathrm{Ni}$} & 231.604 & 0.67 & $7 \times 10^{-4}$ & 50 \\
\hline \multirow[t]{3}{*}{$\mathrm{Ga}$} & 417.206 & 0.14 & $1 \times 10^{-4}$ & 500 & & 221.648 & 0.42 & $4 \times 10^{-4}$ & 0.05 \\
\hline & 294.364 & 0.53 & $5 \times 10^{-4}$ & 50 & & 232.003 & 1.89 & $1.9 \times 10^{-3}$ & 50 \\
\hline & 287.424 & 17.12 & $1.7 \times 10^{-2}$ & 50 & & 227.021 & 1.01 & $1 \times 10^{-3}$ & 100 \\
\hline \multirow[t]{3}{*}{$\mathrm{La}$} & 408.672 & 0.26 & $3 \times 10^{-4}$ & 200 & & 174.828 & $\#$ & Rejected & 100 \\
\hline & 333.749 & 0.25 & $3 \times 10^{-4}$ & 500 & & 300.249 & 13.25 & $1.3 \times 10^{-3}$ & 100 \\
\hline & 379.478 & 0.81 & $8 \times 10^{-4}$ & 100 & & 341.476 & 0.34 & $3 \times 10^{-4}$ & 500 \\
\hline
\end{tabular}

* No interference, \# significant interference. 
TABLE VI

Analytical Performance of Ca, B, Co, Fe, Ga, La, Ni, Pr, Tl, Ce, Pb, Al, and In Analytes the Presence of Gd

\begin{tabular}{|c|c|c|c|c|c|c|c|}
\hline $\begin{array}{l}\text { Ele - } \\
\text { ments }\end{array}$ & $\begin{array}{l}\text { Analytical } \\
\text { Lines } \\
(\mathrm{nm})\end{array}$ & $\begin{array}{c}\text { D.L. } \\
(\mathrm{mg} / \mathrm{L})\end{array}$ & $\begin{array}{c}\text { Sensitivity } \\
\text { (counts/) } \\
\mathrm{mg} / \mathrm{L})\end{array}$ & $\begin{array}{l}\text { Ele- } \\
\text { ments }\end{array}$ & $\begin{array}{l}\text { Analytical } \\
\text { Lines } \\
(\mathrm{nm})\end{array}$ & $\begin{array}{c}\text { D.L. } \\
\text { (mg/L) }\end{array}$ & $\begin{array}{c}\text { Sensitivity } \\
\text { (counts/ } \\
\mathrm{mg} / \mathrm{L} \text { ) }\end{array}$ \\
\hline \multirow[t]{6}{*}{$\mathrm{Ca}$} & 183.801 & 0.799 & 18.7 & \multirow[t]{4}{*}{$\operatorname{Pr}$} & 411.846 & 0.06 & 2705 \\
\hline & 315.887 & 0.15 & 972 & & 414.311 & 0.06 & 3394 \\
\hline & 317.933 & 0.04 & 2936 & & 417.939 & 0.244 & 2958 \\
\hline & 393.366 & 0.0009 & 586502 & & 422.535 & 0.1 & 2628 \\
\hline & 396.847 & 0.002 & 442492 & \multirow[t]{2}{*}{$\mathrm{Tl}$} & 190.864 & 0.055 & 674 \\
\hline & 422.673 & 0.008 & 21893 & & 276.787 & 1 & 19 \\
\hline \multirow[t]{5}{*}{ B } & 136.246 & 14.57 & 0.6 & \multirow[t]{5}{*}{$\mathrm{Ce}$} & 393.373 & 0.26 & 2821 \\
\hline & 182.641 & 0.032 & 554 & & 413.38 & 0.067 & 2413 \\
\hline & 208.959 & 0.019 & 3080 & & 413.765 & 0.058 & 2406 \\
\hline & 249.677 & 0.054 & 787 & & 418.66 & 0.327 & 1968 \\
\hline & 249.773 & 0.024 & 1240 & & 448.691 & 2 & 59.6 \\
\hline \multirow[t]{4}{*}{$\mathrm{Co}$} & 228.616 & 0.052 & 588 & \multirow[t]{4}{*}{$\mathrm{Pb}$} & 220.353 & 0.17 & 219 \\
\hline & 230.786 & 0.076 & 506 & & 261.418 & 0.9 & 53 \\
\hline & 237.862 & 0.025 & 1005 & & 283.305 & 0.08 & 547 \\
\hline & 238.892 & 0.047 & 1459 & & 405.778 & 0.27 & 707 \\
\hline \multirow[t]{10}{*}{$\mathrm{Fe}$} & 238.204 & 0.109 & 524 & \multirow[t]{5}{*}{$\mathrm{Al}$} & 167.078 & 43.6 & 0.5 \\
\hline & 239.562 & 0.019 & 1719 & & 308.215 & 0.041 & 1338 \\
\hline & 241.331 & 0.487 & 137 & & 309.271 & 3.03 & 2539 \\
\hline & 244.451 & 0.26 & 115 & & 394.401 & 0.058 & 3141 \\
\hline & 259.941 & 0.03 & 1223 & & 396.152 & 0.023 & 9690 \\
\hline & 261.187 & 0.05 & 651 & \multirow[t]{4}{*}{ In } & 230.606 & 0.181 & 517 \\
\hline & 262.567 & 0.678 & 93.2 & & 303.609 & 0.323 & 375 \\
\hline & 262.829 & 0.421 & 123 & & 325.609 & 0.055 & 1115 \\
\hline & 275.573 & 0.21 & 222 & & 451.131 & 42 & 16.5 \\
\hline & 373.486 & 0.09 & 2085 & \multirow[t]{7}{*}{$\mathrm{Ni}$} & 174.828 & 11.2 & 1.25 \\
\hline \multirow[t]{3}{*}{$\mathrm{Ga}$} & 287.424 & 0.427 & 155 & & 221.648 & 0.175 & 679 \\
\hline & 294.364 & 0.12 & 642 & & 227.021 & 0.08 & 102 \\
\hline & 417.206 & 0.1 & 7204 & & 231.604 & 0.02 & 651 \\
\hline \multirow[t]{3}{*}{$\mathrm{La}$} & 333.749 & 0.04 & 4104 & & 232.003 & 0.04 & 548 \\
\hline & 379.478 & 0.038 & 6022 & & 300.249 & 0.36 & 440 \\
\hline & 408.672 & 0.033 & 7071 & & 341.476 & 0.01 & 4082 \\
\hline
\end{tabular}

\section{Cobalt (Co)}

Of all analytical lines chosen for for Co $(228.616 \mathrm{~nm}, 230.786 \mathrm{~nm}$, $237.862 \mathrm{~nm}$ and $238.892 \mathrm{~nm}$ ), the least interfered line was found to be $238.892 \mathrm{~nm}$. The detection limit of the lines were evaluated as 0.052 $\mathrm{mg} / \mathrm{L}, 0.076 \mathrm{mg} / \mathrm{L}, 0.025 \mathrm{mg} / \mathrm{L}$, $0.047 \mathrm{mg} / \mathrm{L}$, respectively. The sensitivity followed the trend: 238.892 $\mathrm{nm}>237.862 \mathrm{~nm}>228.616 \mathrm{~nm}>$ $230.786 \mathrm{~nm}$. Therefore, in view of both the spectral interference and the analytical performance, the best line for Co was found to be $238.892 \mathrm{~nm}$.

\section{Iron (Fe)}

Unfortunately, all 10 lines chosen for Fe (238.204 nm, 239.562 $\mathrm{nm}, 241.331 \mathrm{~nm}, 244.451 \mathrm{~nm}$, $259.941 \mathrm{~nm}, 261.187 \mathrm{~nm}, 262.567$ $\mathrm{nm}, 262.829 \mathrm{~nm}, 275.573 \mathrm{~nm}$, and $373.486 \mathrm{~nm}$ ) showed spectral interference from $\mathrm{Gd}$. The least interfered line was $239.562 \mathrm{~nm}$, and with a tolerance level of $50 \mathrm{mg} / \mathrm{L}$ showed comparable analytical performance with rest of the analytical lines and was chosen for the present study.

\section{Gadolinium (Ga)}

The tolerance levels for the analytical lines of $\mathrm{Ga}$ (417.206 nm, $287.424 \mathrm{~nm}$, and $294.364 \mathrm{~nm}$ ) were found to be $500 \mathrm{mg} / \mathrm{L}, 50 \mathrm{mg} / \mathrm{L}$, and $50 \mathrm{mg} / \mathrm{L}$, respectively. In the case of $\mathrm{Ga}$, the least interfered and best performing analytical line was $417.206 \mathrm{~nm}$, with a detection limit of $0.1 \mathrm{mg} / \mathrm{L}$, and a sensitivity of 7203 counts/mg/L. It is, therefore, recommended as the best line for $\mathrm{Ga}$ in the presence of a Gd matrix.

\section{Lanthanum (La)}

Since the three analytical lines for La (333.749 nm, $379.478 \mathrm{~nm}$, and $408.672 \mathrm{~nm}$ ) were interfered by $\mathrm{Gd}$, the analytical performance is the determining factor for choosing the analytical line for trace level determination of $\mathrm{La}$ in a Gd matrix. The detection limit of the three 
lines was found to be comparable and the sensitivity followed the trend: $408.672 \mathrm{~nm}>379.478 \mathrm{~nm}>$ $333.749 \mathrm{~nm}$, respectively. Thus, the $408.672 \mathrm{~nm}$ line is considered best to serve the purpose for this study.

\section{Nickel (Ni)}

Nickel, having line-rich emission spectra, therefore offers more options for choosing alternative interference-free analytical lines. All seven analytical lines of $\mathrm{Ni}$ (174.828 nm, $221.648 \mathrm{~nm}, 227.021$ $\mathrm{nm}, 231.604 \mathrm{~nm}, 232.003 \mathrm{~nm}$, $300.249 \mathrm{~nm}$, and $341.476 \mathrm{~nm}$ ) were interfered by Gd. The $174.828 \mathrm{~nm}$ line interfered most and, hence, was ignored for further investigation. However, the least interfered line was $341.476 \mathrm{~nm}$. It has a tolerance level of $500 \mathrm{mg} / \mathrm{L}$ and a detection limit of $0.01 \mathrm{mg} / \mathrm{L}$. The sensitivity of the lines followed the order: $341.476 \mathrm{~nm}>221.648 \mathrm{~nm}$ $>231.604 \mathrm{~nm}>232.003 \mathrm{~nm}$ $>300.249 \mathrm{~nm}$. The best line selected for this study is $341.476 \mathrm{~nm}$.

\section{Praseodymium (Pr)}

The spectral interference of Gd on the four different analytical lines of $\operatorname{Pr}(411.846 \mathrm{~nm}, 414.311 \mathrm{~nm}$, $417.939 \mathrm{~nm}$, and $422.535 \mathrm{~nm}$ ) revealed that the $411.311 \mathrm{~nm}$ line was not interfered by Gd; however, the analytical performance was not satisfactory. The second least interfered line (414.311 nm) of Pr also showed similar analytical performance. Therefore, the only option was to choose the $414.311 \mathrm{~nm}$ line for further investigation.

\section{Tellurium (T1)}

The $276.787 \mathrm{~nm}$ line of $\mathrm{Tl}$ was found to be more interfered by Gd than the $190.864 \mathrm{~nm}$ line. The analytical performance of these lines revealed that better performance was obtained with the $190.864 \mathrm{~nm}$ line and was chosen for further investigation.

\section{Cesium (Cs)}

Of the five lines of Cs (393.373 $\mathrm{nm}, 413.380 \mathrm{~nm}, 413.765 \mathrm{~nm}$, $418.660 \mathrm{~nm}$, and $448.691 \mathrm{~nm}$ ), the $448.691 \mathrm{~nm}$ and $393.373 \mathrm{~nm}$ lines were significantly interfered from Gd. Though the spectral interference of the other three lines showed similar contribution, the detection limit of these lines ( $413.380 \mathrm{~nm}, 413.765 \mathrm{~nm}$, and $418.66 \mathrm{~nm}$ ) was evaluated as 0.067 $\mathrm{mg} / \mathrm{L}, 0.058 \mathrm{mg} / \mathrm{L}$, and $0.327 \mathrm{mg} / \mathrm{L}$, respectively. The sensitivity of these lines followed the trend: $413.380 \mathrm{~nm}>413.765 \mathrm{~nm}>$ $418.66 \mathrm{~nm}$. Based on the analytical performance of the $413.380 \mathrm{~nm}$ Cs line, it was chosen best for further study.

\section{Lead (Pb)}

Four lines of $\mathrm{Pb}(220.353 \mathrm{~nm}$, $405.778 \mathrm{~nm}, 283.305 \mathrm{~nm}$, and $261.418 \mathrm{~nm}$ ) were chosen for the present study. All of the lines were found to have prominent spectral interference from $\mathrm{Gd}$. The least interfered line ( $405.778 \mathrm{~nm}$ ) was also found to be the most sensitive and, therefore, chosen as the best line for trace level determination of $\mathrm{Pb}$ in a $\mathrm{Gd}$ matrix.

\section{Aluminum (A1)}

Of the five analytical lines of Al (167.078 nm, $308.215 \mathrm{~nm}, 309.271$ $\mathrm{nm}, 394.401 \mathrm{~nm}$, and $396.152 \mathrm{~nm}$ ), the least interfered with Gd was $396.152 \mathrm{~nm}$. The tolerance level of $200 \mathrm{mg} / \mathrm{L}$ and a correction factor of $0.000104 \mathrm{mg} / \mathrm{L}$ per $1000 \mathrm{mg} / \mathrm{L}$ of Gd showed the best analytical performance (detection limit $0.023 \mathrm{mg} / \mathrm{L}$ and sensitivity 9690.35 counts/ $\mathrm{mg} / \mathrm{L})$. Hence, it was found to be suitable for Al determination in the presence of a Gd matrix.

\section{Indium (In)}

Of the four analytical lines of In (230.606 nm, 325.609 nm, 451.131 $\mathrm{nm}$, and $303.609 \mathrm{~nm})$, the 451.131 nm line showed no spectral inter- ference from Gd, but had the worst analytical performance (detection limit and sensitivity). Therefore, for this study, the $325.609 \mathrm{~nm}$ line is the best.

The typical spectral interference from different concentrations of Gd on the Nd $406.109 \mathrm{~nm}, \mathrm{Al}$ $308.215 \mathrm{~nm}$, Ce $448.691 \mathrm{~nm}$, and Dy $364.540 \mathrm{~nm}$ lines are shown in Figure 3 (a), (b), (c), (d), respectively.

\section{Direct Determination of Analytes Without Chemical Separation}

Based on the spectral interference of Gd on the different analytical lines mentioned above and their analytical performance, a methodology was developed for the determination of these analytes in a Gd matrix without chemical separation. This not only saves time, but also decreases the chance of contamination and sample handling which is very important for trace impurity analyses. On this basis, the analytical performance (detection limit, sensitivity) and spectral interference data, the suitable lines for all of the analytes in this study obtained were as follows: Ag $328.068 \mathrm{~nm}$, Ba $455.404 \mathrm{~nm}$, Bi $306.772 \mathrm{~nm}$, Cd $226.502 \mathrm{~nm}$, Cr $205.618 \mathrm{~nm}$, Cu $324.754 \mathrm{~nm}$, Dy $353.170 \mathrm{~nm}$, Li $670.780 \mathrm{~nm}$, Lu $2611.542 \mathrm{~nm}$, Mg $279.553 \mathrm{~nm}$, Mn $257.611 \mathrm{~nm}$, $\mathrm{Na} 589.592 \mathrm{~nm}, \mathrm{Na} 401.225 \mathrm{~nm}$, Sr $407.771 \mathrm{~nm}, \mathrm{Zn} 213.856 \mathrm{~nm}$, Ca 393.366 nm, B 208,959 nm, Co $205.618 \mathrm{~nm}$, Fe $239.562 \mathrm{~nm}$, Ga 417.206 nm, La $408.672 \mathrm{~nm}$, Ni $341.476 \mathrm{~nm}, \operatorname{Pr} 411.846 \mathrm{~nm}$, $\mathrm{Pb} 405.778 \mathrm{~nm}, \mathrm{Al} 396.152 \mathrm{~nm}$, and In $325.609 \mathrm{~nm}$. For all of the analytes, the contributions due to the spectral interference of $\mathrm{Gd}$ were found to be linear with the concentrations of $\mathrm{Gd}$ fed into the plasma. The correction factors (C.F.) were calculated as a ratio of contribution $(\mathrm{mg} / \mathrm{L})$ on the analytical line due to a pure Gd solution 


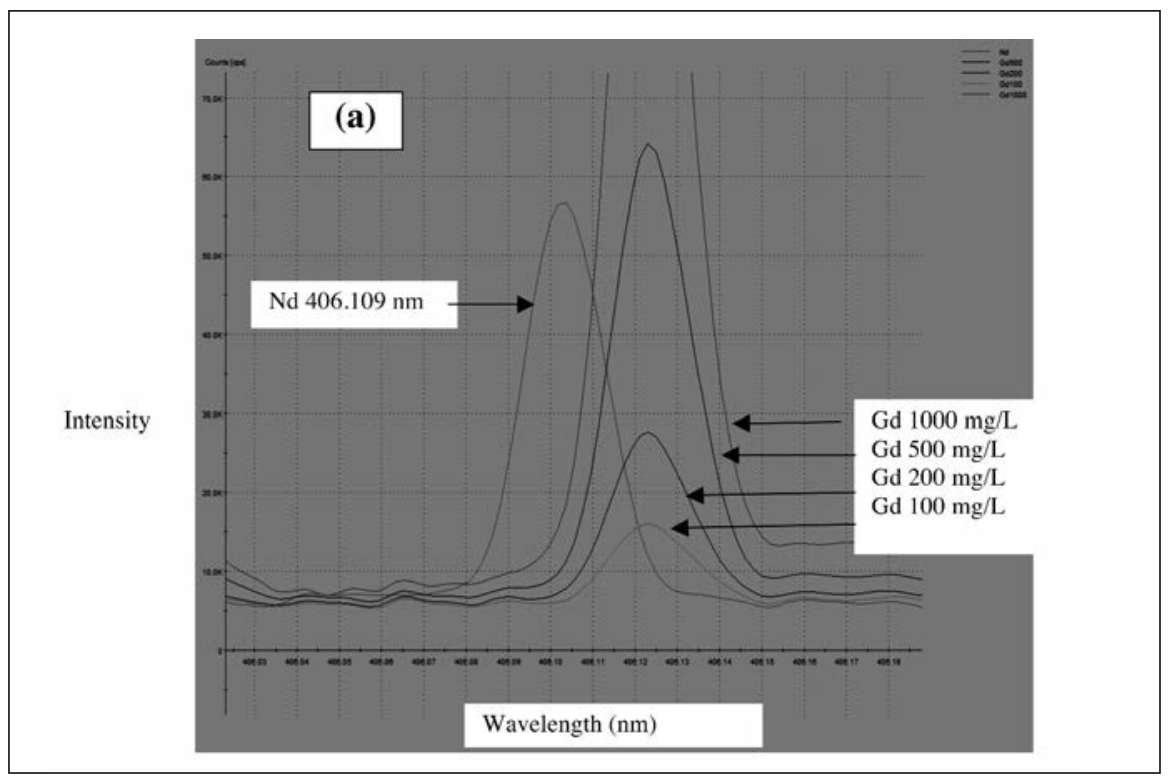

Fig. 3(a). Spectral interference of Gd on $\mathrm{Nd} 406.109 \mathrm{~nm}$.

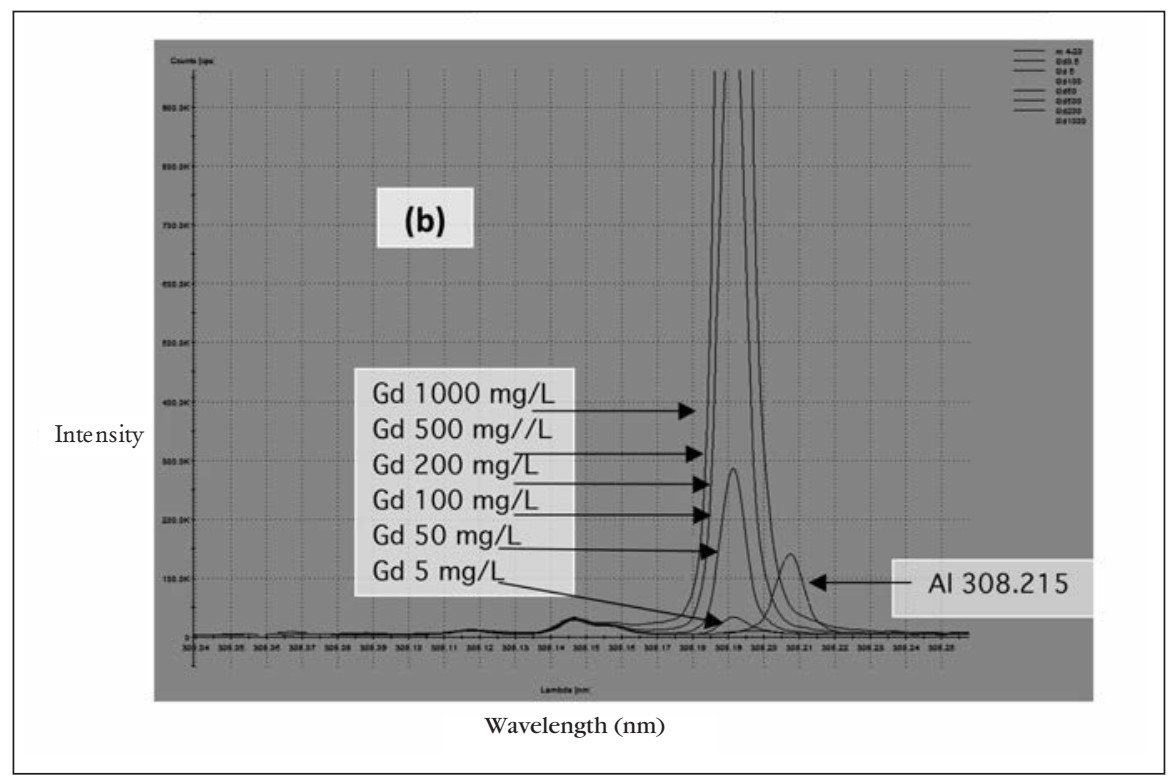

Fig. 3(b). Spectral interference of Gd on Al $308.215 \mathrm{~nm}$.

\section{Atomic Apectroscopy \\ Vol. 36(1), Jan./Feb. 2015}

(C*) to the concentration of $\mathrm{Gd}$ $(\mathrm{mg} / \mathrm{L})$ solution $(\mathrm{CGd})$ :

$$
\text { C.F. }=C^{*} / \mathrm{C} \text { Gd }
$$

In view of the above studies, two synthetic samples (S1 and S2) were prepared for $\mathrm{Ag}, \mathrm{Ba}, \mathrm{Bi}, \mathrm{Cd}$, $\mathrm{Cr}, \mathrm{Cu}, \mathrm{Dy}, \mathrm{Li}, \mathrm{Lu}, \mathrm{Mg}, \mathrm{Mn}, \mathrm{Na}, \mathrm{Nd}$, $\mathrm{Sr}$, and $\mathrm{Zn}$. Sample S1 contained all of the above analytes at $0.1 \mathrm{mg} / \mathrm{L}$ and $\mathrm{Gd}$ at $1000 \mathrm{mg} / \mathrm{L}$, while the second sample, S2, contained 1.0 $\mathrm{mg} / \mathrm{L}$ of the above-mentioned analytes along with $1000 \mathrm{mg} / \mathrm{L}$ of Gd. The results, listed in Table VII, reveal that $\mathrm{Ag}, \mathrm{Ba}, \mathrm{Bi}, \mathrm{Cd}, \mathrm{Cr}, \mathrm{Cu}$, $\mathrm{Dy}, \mathrm{Li}, \mathrm{Lu}, \mathrm{Mg}, \mathrm{Mn}, \mathrm{Na}, \mathrm{Nd}, \mathrm{Sr}$, and $\mathrm{Zn}$ can be determined even at the $0.1 \mathrm{mg} / \mathrm{L}$ level in the presence of a Gd matrix $(1000 \mathrm{mg} / \mathrm{L})$ without chemical separation.

Two synthetic samples were prepared for $\mathrm{Ca}, \mathrm{B}, \mathrm{Co}, \mathrm{Fe}, \mathrm{Ga}, \mathrm{La}, \mathrm{Ni}$, $\mathrm{Pr}$, and T1. Sample S3 consisted of $0.2 \mathrm{mg} / \mathrm{L}$ of each specified analyte along with $1000 \mathrm{mg} / \mathrm{L}$ of $\mathrm{Gd}$, while sample $\mathrm{S} 4$ consisted of $2 \mathrm{mg} / \mathrm{L}$ of these analytes along with 1000 $\mathrm{mg} / \mathrm{L}$ of $\mathrm{Gd}$. The results for these samples are summarized in Table VIII which revealed that these analytes can be estimated as low as $0.2 \mathrm{mg} / \mathrm{L}$ of concentration in a $\mathrm{Gd}$ matrix.

A similar study of $\mathrm{Ce}$ and $\mathrm{Pb}$ with synthetic samples S5 and S6 revealed that these two analytes can be estimated as low as $2 \mathrm{mg} / \mathrm{L}$ concentration in a $\mathrm{Gd}$ matrix (see Table IX). The synthetic sample S5 contained $2.0 \mathrm{mg} / \mathrm{L}$ of $\mathrm{Ce}$ and $\mathrm{Pb}$ along with $1000 \mathrm{mg} / \mathrm{L}$ of $\mathrm{Gd}$, while sample $\mathrm{S} 6$ contained $10 \mathrm{mg} / \mathrm{L}$ of $\mathrm{Ce}$ and $\mathrm{Pb}$ in $1000 \mathrm{mg} / \mathrm{L}$ of Gd matrix.

\section{Comparison of Present Method With Other Analytical Methods}

An attempt was made to compare the analytical results of the synthetic samples using the proposed methodology with that of other existing analytical methods. The synthetic samples contained $0.5 \mathrm{mg} / \mathrm{L}$ of $\mathrm{Ag}, \mathrm{Ba}, \mathrm{Bi}, \mathrm{Cd}$, 


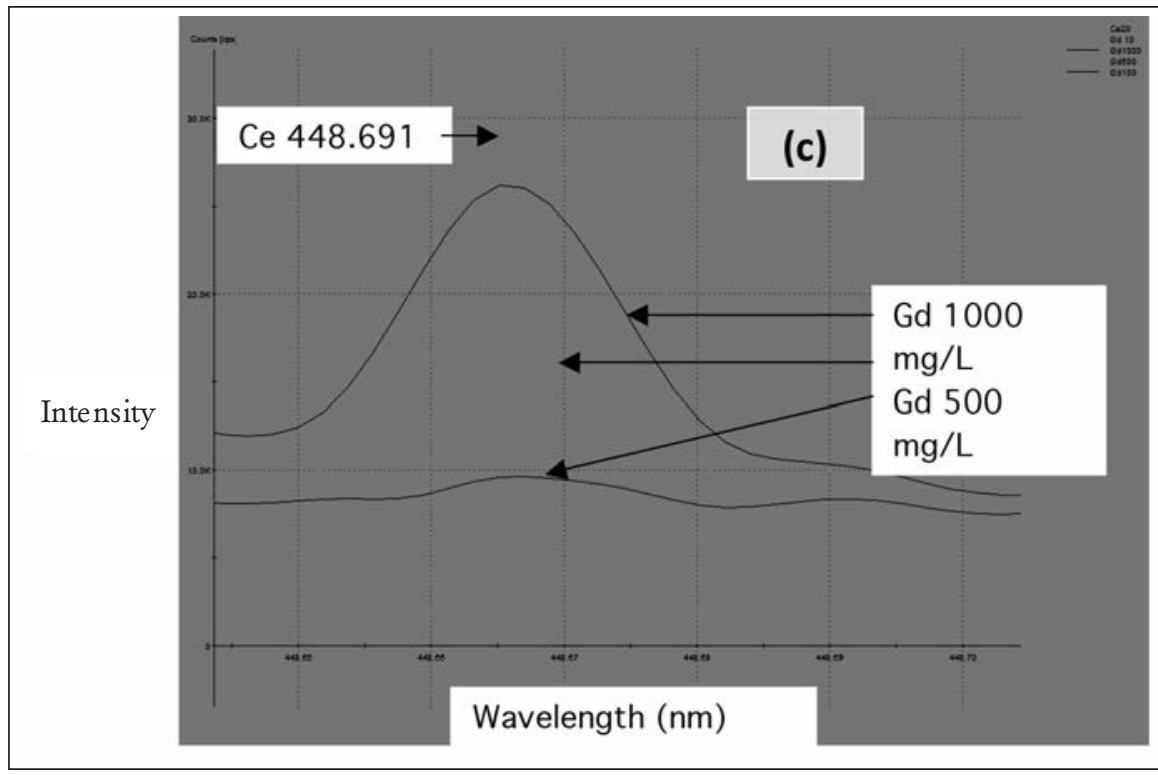

Fig. 3(c). Spectral interference of Gd on Ce $338.691 \mathrm{~nm}$.

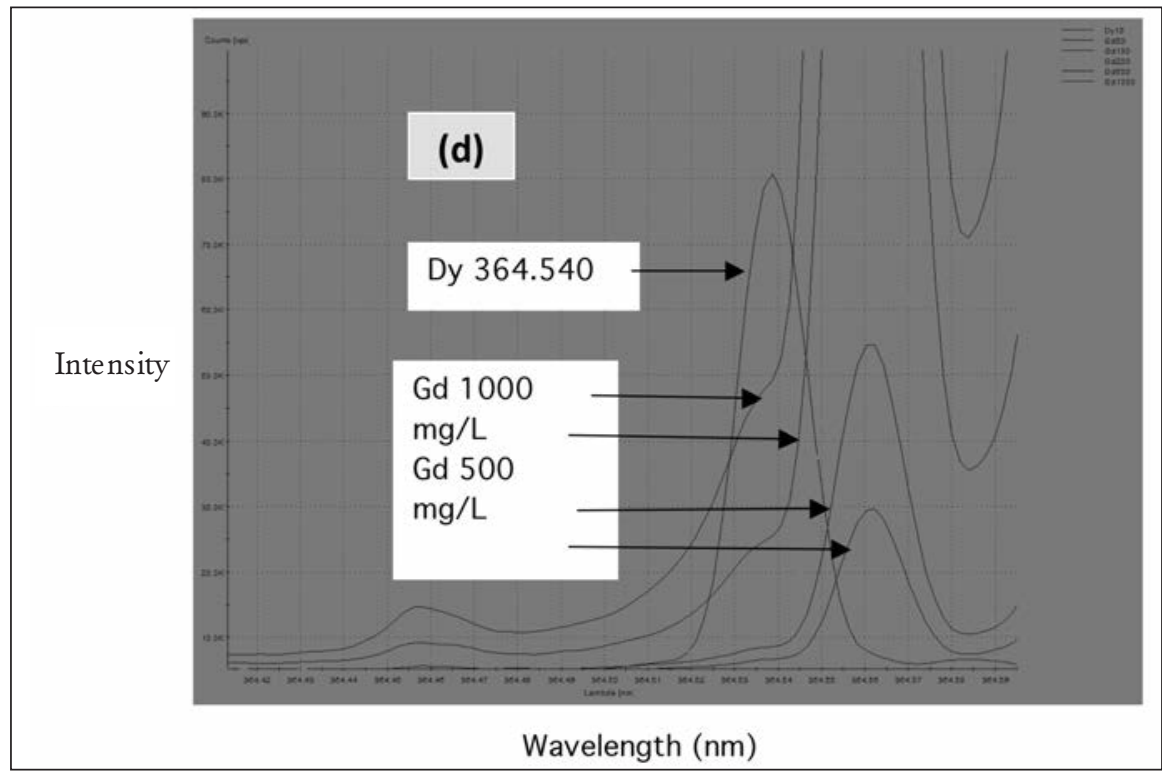

Fig. 3(d). Spectral interference of $G d$ on Dy $364.540 \mathrm{~nm}$.
Cr, Cu, Dy, Li, Lu, Mg, Mn, Na, Nd, $\mathrm{Sr}$, and $\mathrm{Zn} ; 1 \mathrm{mg} / \mathrm{L}$ concentration of $\mathrm{Ca}, \mathrm{B}, \mathrm{Co}, \mathrm{Fe}, \mathrm{Ga}, \mathrm{La}, \mathrm{Ni}, \mathrm{Pr}, \mathrm{Tl}$; and $5 \mathrm{mg} / \mathrm{L}$ of $\mathrm{Ce}$ and $\mathrm{Pb}$ in $1000 \mathrm{mg} / \mathrm{L}$ of $\mathrm{Gd}$. The synthetic sample was directly fed to the plasma for analysis without any chemical separation. The results were corrected for spectral interference of Gd using the correction factors evaluated previously. The analytical results thus obtained were compared with existing analytical techniques. For $\mathrm{Ag}$, the atomic absorption spectroscopic technique was used for comparison purposes (32). For $\mathrm{Ba}, \mathrm{Bi}$, $\mathrm{Cd}, \mathrm{Cr}, \mathrm{Cu}, \mathrm{Li}, \mathrm{Mg}, \mathrm{Mn}, \mathrm{Na}, \mathrm{Sr}, \mathrm{Zn}$, $\mathrm{Ca}, \mathrm{B} \mathrm{Co}, \mathrm{Fe}, \mathrm{Ga}, \mathrm{Ni}, \mathrm{Tl}$ and $\mathrm{Pb}$, the D.C. arc carrier distillation technique (33-35) was used, while mainly for rare earth elements (Dy, Ce, Lu, Nd, La, and Pr), ion chromatography was employed (36). The results obtained by the present method were found to compare well with the existing methods.

\section{CONCLUSION}

A systematic study was performed on the spectral interference of $\mathrm{Gd}$ on $\mathrm{Ag}, \mathrm{Ba}, \mathrm{Bi}, \mathrm{Cd}, \mathrm{Cr}, \mathrm{Cu}, \mathrm{Dy}, \mathrm{Li}$, $\mathrm{Mg}, \mathrm{Mn}, \mathrm{Na}, \mathrm{Nd}, \mathrm{Sr}, \mathrm{Zn}, \mathrm{Ca}, \mathrm{B}, \mathrm{Co}$, $\mathrm{Fe}, \mathrm{Ga}, \mathrm{La}, \mathrm{Ni}, \mathrm{Pr}, \mathrm{Tl}, \mathrm{Ce}, \mathrm{Pb}, \mathrm{Al}$, and In. The analytical performance of the different analytical lines of these analytes revealed that the best lines for the determination of these analytes in a Gd matrix are as follows: Ag $328.068 \mathrm{~nm}$, Ba 455.404 nm, Bi 306.772 nm, Cd $226.502 \mathrm{~nm}$, Cr $205.618 \mathrm{~nm}$, $\mathrm{Cu} 324.754 \mathrm{~nm}$, Dy $353.170 \mathrm{~nm}$, Li $670.780 \mathrm{~nm}$, Lu $2611.542 \mathrm{~nm}$, Mg $279.553 \mathrm{~nm}$, Mn $257.611 \mathrm{~nm}$, $\mathrm{Na} 589.592 \mathrm{~nm}, \mathrm{Na} 401.225 \mathrm{~nm}$, Sr $407.771 \mathrm{~nm}, \mathrm{Zn} 213.856 \mathrm{~nm}$, Ca 393.366 nm, B 208,959 nm, Co $205.618 \mathrm{~nm}$, Fe $239.562 \mathrm{~nm}$, Ga 417.206 nm, La $408.672 \mathrm{~nm}$, Ni $341.476 \mathrm{~nm}, \operatorname{Pr} 411.846 \mathrm{~nm}$, $\mathrm{Pb} 405.778 \mathrm{~nm}$, Al $396.152 \mathrm{~nm}$, and In $325.609 \mathrm{~nm}$. It was also observed that $\mathrm{Ag}, \mathrm{Ba}, \mathrm{Bi}, \mathrm{Cd}, \mathrm{Cr}$, $\mathrm{Cu}, \mathrm{Dy}, \mathrm{Li}, \mathrm{Lu}, \mathrm{Mg}, \mathrm{Mn}, \mathrm{Na}, \mathrm{Nd}, \mathrm{Sr}$, and $\mathrm{Zn}$ can be deter-mined at the 


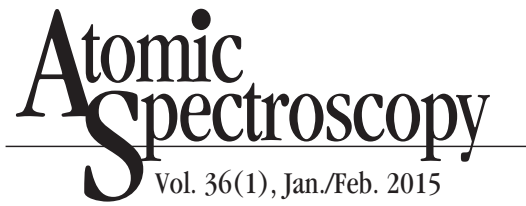

$0.1 \mathrm{mg} / \mathrm{L}$ level, while $\mathrm{Ca}, \mathrm{B}, \mathrm{Co}, \mathrm{Fe}$, $\mathrm{Ga}, \mathrm{La}, \mathrm{Ni}, \mathrm{Pr}$, and $\mathrm{Tl}$ can be determined at $0.2 \mathrm{mg} / \mathrm{L}$ in the presence of a Gd matrix.

The methodology developed for the direct determination of these analytes in the presence of a Gd matrix without any chemical separation was validated using synthetic samples prepared from a commercially available standard reference material solution of the individual elements. The newly developed methodology was also compared with current analytical techniques and the results were found to be in good agreement.

\section{ACKNOWLEDGMENT}

The authors wish to acknowledge the constant support and keen interest of Dr. A.Goswami, Head, Radiochemistry Division in this work.

$\overline{\text { Received August 13, } 2014 .}$
TABLE VII

Analyses of Synthetic Samples Containing Analytes Ag, Ba, Bi, Cd, Cr, $\mathrm{Cu}, \mathrm{Dy}, \mathrm{Li}, \mathrm{Lu}, \mathrm{Mg}, \mathrm{Mn}, \mathrm{Na}, \mathrm{Nd}$, Sr, and $\mathrm{Zn}$ in Gd Matrix

\begin{tabular}{lc|cc|cc}
\hline $\begin{array}{l}\text { Ele- } \\
\text { ments }\end{array}$ & $\begin{array}{c}\text { Analytical } \\
\text { Lines } \\
(\mathrm{nm})\end{array}$ & $\begin{array}{c}\text { Actual } \\
\text { Concen- } \\
\text { tration } \\
(\mathrm{mg} / \mathrm{L})\end{array}$ & $\begin{array}{c}\text { S1 } \\
\text { Amount } \\
\text { Estimated } \\
\text { After } \\
\text { Inorporating } \\
\text { Correction } \\
\text { Factor } \\
\text { (mg/L) }\end{array}$ & $\begin{array}{c}\text { S2 } \\
\text { Actual } \\
\text { tration } \\
(\mathrm{mg} / \mathrm{L})\end{array}$ & $\begin{array}{c}\text { Amount } \\
\text { Estimated } \\
\text { After } \\
\text { Incorporating } \\
\text { Correction } \\
\text { Factor } \\
\text { (mg/L) }\end{array}$ \\
\hline $\mathrm{Ag}$ & 328.068 & 0.1 & $0.099 \pm 0.010$ & 1 & $0.99 \pm 0.099$ \\
$\mathrm{Ba}$ & 455.404 & 0.1 & $0.089 \pm 0.008$ & 1 & $0.89 \pm 0.089$ \\
$\mathrm{Bi}$ & 306.772 & 0.1 & $0.11 \pm 0.011$ & 1 & $1.2 \pm 0.120$ \\
$\mathrm{Cd}$ & 226.502 & 0.1 & $0.13 \pm 0.013$ & 1 & $1.3 \pm 0.130$ \\
$\mathrm{Cr}$ & 205.618 & 0.1 & $0.098 \pm 0.010$ & 1 & $0.98 \pm 0.098$ \\
$\mathrm{Cu}$ & 324.754 & 0.1 & $0.091 \pm 0.009$ & 1 & $0.91 \pm 0.091$ \\
$\mathrm{Dy}$ & 353.17 & 0.1 & $0.099 \pm 0.010$ & 1 & $0.99 \pm 0.099$ \\
$\mathrm{Li}$ & 670.78 & 0.1 & $0.11 \pm 0.011$ & 1 & $1.1 \pm 0.110$ \\
$\mathrm{Lu}$ & 261.542 & 0.1 & $0.095 \pm 0.009$ & 1 & $0.95 \pm 0.095$ \\
$\mathrm{Mg}$ & 279.553 & 0.1 & $0.12 \pm 0.012$ & 1 & $1.2 \pm 0.120$ \\
$\mathrm{Mn}$ & 257.611 & 0.1 & $0.11 \pm 0.011$ & 1 & $1.1 \pm 0.110$ \\
$\mathrm{Na}$ & 589.592 & 0.1 & $0.13 \pm 0.013$ & 1 & $1.3 \pm 0.130$ \\
$\mathrm{Nd}$ & 401.225 & 0.1 & $0.098 \pm 0.010$ & 1 & $0.98 \pm 0.098$ \\
$\mathrm{Sr}$ & 407.771 & 0.1 & $0.12 \pm 0.012$ & 1 & $1.2 \pm 0.120$ \\
$\mathrm{Zn}$ & 213.856 & 0.1 & $0.093 \pm 0.009$ & 1 & $0.93 \pm 0.093$ \\
\hline
\end{tabular}

TABLE VIII

Analyses of Synthetic Samples Containing Analytes Ca, B, Co, Fe, Ga, La, Ni, Pr, and Tl in Gd Matrix

\begin{tabular}{|c|c|c|c|c|c|c|c|}
\hline $\begin{array}{l}\text { Ele- } \\
\text { ments }\end{array}$ & $\begin{array}{l}\text { Analytical } \\
\text { Lines } \\
\text { (nm) }\end{array}$ & $\begin{array}{l}\text { Actual } \\
\text { Concen- } \\
\text { tration } \\
(\mathrm{mg} / \mathrm{L})\end{array}$ & $\begin{array}{c}\text { S3 } \\
\text { Amount } \\
\text { Estimated } \\
\text { Before } \\
\text { Incorporating } \\
\text { Correction } \\
\text { Factor } \\
(\mathrm{mg} / \mathrm{L})\end{array}$ & $\begin{array}{c}\text { Amount } \\
\text { Estimated } \\
\text { After } \\
\text { Incorporating } \\
\text { Correction } \\
\text { Factor } \\
(\mathrm{mg} / \mathrm{L})\end{array}$ & $\begin{array}{l}\text { Actual } \\
\text { Concen- } \\
\text { tration } \\
(\mathrm{mg} / \mathrm{L})\end{array}$ & $\begin{array}{c}\mathbf{S 4} \\
\text { Amount } \\
\text { Estimated } \\
\text { Before } \\
\text { Incorporating } \\
\text { Correction } \\
\text { Factor } \\
(\mathrm{mg} / \mathrm{L})\end{array}$ & $\begin{array}{l}\text { Amount } \\
\text { Estimated } \\
\text { After } \\
\text { Incorporating } \\
\text { Correction } \\
\text { Factor } \\
(\mathrm{mg} / \mathrm{L})\end{array}$ \\
\hline $\mathrm{Ca}$ & 393.366 & 0.2 & $0.445 \pm 0.022$ & $0.203 \pm 0.010$ & 2 & $2.272 \pm 0.113$ & $2.03 \pm 0.101$ \\
\hline B & 208.959 & 0.2 & $0 . .304 \pm 0.015$ & $0.226 \pm 0.011$ & 2 & $2.038 \pm 0.101$ & $1.96 \pm 0.098$ \\
\hline Co & 238.892 & 0.2 & $0.427 \pm 0.021$ & $0.202 \pm 0.010$ & 2 & $2.345 \pm 0.117$ & $2.12 \pm 0.106$ \\
\hline $\mathrm{Fe}$ & 239.562 & 0.2 & $0.400 \pm 0.020$ & $0.221 \pm 0.011$ & 2 & $2.289 \pm 0.114$ & $2.11 \pm 0.105$ \\
\hline $\mathrm{Ga}$ & 417.206 & 0.2 & $0.348 \pm 0.017$ & $0.213 \pm 0.010$ & 2 & $2.115 \pm 0.106$ & $1.98 \pm 0.099$ \\
\hline $\mathrm{La}$ & 408.672 & 0.2 & $0.447 \pm 0.022$ & $0.191 \pm 0.0095$ & 2 & $2.166 \pm 0.108$ & $1.91 \pm 0.095$ \\
\hline $\mathrm{Ni}$ & 341.476 & 0.2 & $0.527 \pm 0.026$ & $0.187 \pm 0.0093$ & 2 & $2.310 \pm 0.115$ & $1.97 \pm 0.098$ \\
\hline $\operatorname{Pr}$ & 411.846 & 0.2 & $0.470 \pm 0.023$ & $0.191 \pm 0.0095$ & 2 & $2.389 \pm 0.119$ & $2.11 \pm 0.105$ \\
\hline $\mathrm{Tl}$ & 190.864 & 0.2 & $0.506 \pm 0.025$ & $0.185 \pm 0.0092$ & 2 & $2.271 \pm 0.113$ & $1.95 \pm 0.097$ \\
\hline
\end{tabular}


TABLE IX

Analyses of Synthetic Samples Containing $\mathrm{Ce}$ and $\mathrm{Pb}$ in Gd Matrix

\begin{tabular}{|c|c|c|c|c|c|c|c|}
\hline $\begin{array}{l}\text { Ele- } \\
\text { ments }\end{array}$ & $\begin{array}{l}\text { Analytical } \\
\text { Lines } \\
\text { (nm) }\end{array}$ & $\begin{array}{l}\text { Actual } \\
\text { Concen-. } \\
\text { tration } \\
(\mathrm{mg} / \mathrm{L})\end{array}$ & $\begin{array}{c}\text { S5 } \\
\text { Amount } \\
\text { Estimated } \\
\text { Before } \\
\text { Incorporating } \\
\text { Correction } \\
\text { Factor } \\
(\mathrm{mg} / \mathrm{L})\end{array}$ & $\begin{array}{c}\text { Amount } \\
\text { Estimated } \\
\text { After } \\
\text { Incorporating } \\
\text { Correction } \\
\text { Factor } \\
(\mathrm{mg} / \mathrm{L})\end{array}$ & $\begin{array}{l}\text { Actual } \\
\text { Concen-. } \\
\text { tration } \\
(\mathrm{mg} / \mathrm{L})\end{array}$ & $\begin{array}{c}\text { S6 } \\
\text { Amount } \\
\text { Estimated } \\
\text { Before } \\
\text { Incorporating } \\
\text { Correction } \\
\text { Factor } \\
(\mathrm{mg} / \mathrm{L})\end{array}$ & $\begin{array}{c}\text { Amount } \\
\text { Estimated } \\
\text { After } \\
\text { Incorporating } \\
\text { Correction } \\
\text { Factor } \\
(\mathrm{mg} / \mathrm{L})\end{array}$ \\
\hline $\mathrm{Ce}$ & 413.38 & 2 & $2.921 \pm 0.146$ & $2.11 \pm 0.105$ & 10 & $10.931 \pm 0.546$ & $10.12 \pm 0.506$ \\
\hline $\mathrm{Pb}$ & 405.778 & 2 & $6.151 \pm 0.307$ & $1.96 \pm 0.098$ & 10 & $14.101 \pm 0.705$ & $9.91 \pm 0.495$ \\
\hline
\end{tabular}

TABLE X

Analysis of Synthetic Samples by Present Method and Its Comparison with Existing Method

\begin{tabular}{llll}
\hline Elements & $\begin{array}{c}\text { Analytical } \\
\text { Lines } \\
(\mathrm{nm})\end{array}$ & $\begin{array}{c}\text { Estimated by } \\
\text { Present Method } \\
(\mathrm{mg} / \mathrm{L})\end{array}$ & $\begin{array}{c}\text { Comparison with } \\
\text { Other Method } \\
(\mathrm{mg} / \mathrm{L})\end{array}$ \\
\hline $\mathrm{Ag}$ & 328.068 & $0.52 \pm 0.03$ & $0.47 \pm 0.05^{*}$ \\
$\mathrm{Ba}$ & 455.404 & $0.48 \pm 0.01$ & $0.46 \pm 0.06^{* *}$ \\
$\mathrm{Bi}$ & 306.772 & $0.50 \pm 0.03$ & $0.51 \pm 0.02^{* *}$ \\
$\mathrm{Cd}$ & 226.502 & $0.53 \pm 0.04$ & $0.50 \pm 0.05^{* *}$ \\
$\mathrm{Cr}$ & 205.618 & $0.48 \pm 0.03$ & $0.53 \pm 0.04^{* *}$ \\
$\mathrm{Cu}$ & 324.754 & $0.49 \pm 0.02$ & $0.54 \pm 0.06^{* *}$ \\
$\mathrm{Dy}$ & 353.17 & $0.52 \pm 0.03$ & $0.46 \pm 0.04^{*}$ \\
$\mathrm{Li}$ & 670.78 & $0.52 \pm 0.02$ & $0.48 \pm 0.03^{* *}$ \\
$\mathrm{Lu}$ & 261.542 & $0.48 \pm 0.02$ & $0.51 \pm 0.03^{*}$ \\
$\mathrm{Mg}$ & 279.553 & $0.50 \pm 0.04$ & $0.52 \pm 0.04^{* *}$ \\
$\mathrm{Mn}$ & 257.611 & $0.50 \pm 0.04$ & $0.49 \pm 0.04^{* *}$ \\
$\mathrm{Na}$ & 589.592 & $0.47 \pm 0.03$ & $0.46 \pm 0.04^{* *}$ \\
$\mathrm{Nd}$ & 401.225 & $0.47 \pm 0.02$ & $0.52 \pm 0.03^{*}$ \\
$\mathrm{Sr}$ & 407.771 & $0.51 \pm 0.02$ & $0.54 \pm 0.04^{* *}$ \\
$\mathrm{Zn}$ & 213.856 & $0.52 \pm 0.03$ & $0.47 \pm 0.03^{* *}$ \\
$\mathrm{Ca}$ & 393.366 & $1.11 \pm 0.06$ & $0.97 \pm 0.08^{* *}$ \\
$\mathrm{~B}$ & 208.959 & $0.97 \pm 0.07$ & $1.2 \pm 0.09^{* *}$ \\
$\mathrm{Co}$ & 238.892 & $1.05 \pm 0.06$ & $0.98 \pm 0.08^{* *}$ \\
$\mathrm{Fe}$ & 239.562 & $0.99 \pm 0.05$ & $1.02 \pm 0.06^{* *}$ \\
$\mathrm{Ga}$ & 417.206 & $0.98 \pm 0.07$ & $1.2 \pm 0.07^{* *}$ \\
$\mathrm{La}$ & 408.672 & $1.08 \pm 0.05$ & $1.11 \pm 0.06^{*}$ \\
$\mathrm{Ni}$ & 341.476 & $0.98 \pm 0.06$ & $0.97 \pm 0.06^{* *}$ \\
$\mathrm{Pr}$ & 411.846 & $1.12 \pm 0.09$ & $1.2 \pm 0.09^{*}$ \\
$\mathrm{Tl}$ & 190.864 & $1.08 \pm 0.07$ & $0.94 \pm 0.07^{* *}$ \\
$\mathrm{Ce}$ & 413.38 & $5.2 \pm 0.3$ & $4.7 \pm 0.4^{*}$ \\
$\mathrm{~Pb}$ & 405.778 & $4.8 \pm 0.2$ & $5.1 \pm 0.3^{* *}$ \\
\hline & &
\end{tabular}

Note: The Gd concentration in the synthetic sample is $1000 \mathrm{mg} / \mathrm{L}$;

\# refers to the analysis by Atomic Absorption Spectrometry;

** refers to the analysis by D.C. Arc carrier distillation technique;

* refers to the analysis by chromatographic technique. 


\section{REFERENCES}

1. A.A. Argekar, M.J. Kulkarni, J.N. Mathur, and A.G. Page, Talanta 56, 591(2002).

2. S. Greenfield, I.LL. Jones, and C.T. Berry, Analyst 89,713 (1964).

3. R.H. Wendt and V.A. Fassel, Anal. Chem.37, 920 (1965).

4. V.A. Fassel and R.N. Kniseley, Anal. Chem. 46, 1110A (1974).

5. V.A. Fassel, Anal. Chem. 51,1290A (1979).

6. P.W.J.M. Boumans, and J.J.A.M. Vrakking, Spectrochim. Acta B 40, 1085 (1985).

7. P.W.J.M. Boumans, and J.J.A.M. Vrakking, Spectrochim. Acta 42, 819 (1987).

8. C. Moor, T. Lymberopoulou, and V.J. Dietrich, Mikrochim. Acta 136, 123 (2001).

9. J. P.Robin, Pro. Anal. At. Spectrom. 5, 79 (1982).

10. M. H. Abdallah, J. M. Mermet, and C. Trassy, Anal. Chim. Acta 87, 329 (1976).

11. A. Mazzucotellit, F. De Paz, E. Magi, R. Frache, Anal. Sci. 8, 189 (1992).

12. A. Sengupta, M.J. Kulkarni, S.V. Godbole, V. Natarajan, and P.N. Pathak, At. Spectrosc. 35(2), 60 (2014).

13. A. Sengupta, M. J. Kulkarni, and S. V. Godbole, J. Radioanal. Nucl. Chem 289, 961 (2011).

14. B. Rajeswari, B.A. Dhawale, T.R. Bangia, J.N. Mathur, and A.G. Page, ,J. Radioanal. Nucl.Chem. 254, 479 (2002).

15. R.K. Malhotra, and K. Satyanarayana, Talanta 50, 601 (1999).

16. C. Mahan, S. Bonchin, D. Figg, D. Gcrth and C. Collier, J. Anal. Atom. Spectrom. 15, 929 (2000).

17. S. Marin, S. Cornejo, C. Jara, and N. Duran, Fresenius' J. Anal. Chem. 355, 680 (1996).
P.W.J.M. Boumans, Spectrochim. Acta Part B 40, 173 (1988).

19. N. Daskalova, S. Velichkov, N. Krasnobaeva, and P. Slavova, Spectrochim. Acta B47, E1595 (1992).

20. S. Velichkov, N. Daskalova, and P. Slavova, Spectrochim. Acta B48, E1743 (1993).

21. N. Daskalova, S. Velichkov, and P. Slavova, Spectrochim. Acta B51, 733 (1996).

22. S. Velichkov, E. Kostadinova, and N. Daskalova, Spectrochim. Acta B53, 1863 (1998).

23. E. Kostadinova, L. Aleksieva, S. Velichkov, and N. Daskalova Spectrochim. Acta B55, 689 (2000).

24. L. Aleksieva, N. Daskalova, and S. Velichkov, Spectrochim. Acta B 57, 1339 (2002).

25. I. Kolibarska, S. Velichkov, and N. Daskalova, Spectrochim. Acta B63, 603 (2008).

26. L. Goldstein, and A.A. Strasser, Nucl. Technol. 60, 352 (1983).

27. A. Galperin, M. Segev, and A. Radkowsky, Nucl. Technol. 75, 123 (1986).

28. K.S. Choi, C.H. Lee, J.G. Kim, W.H. Kim, and J.G. Kang, Talanta 71, 662 (2007).

29. V.C. Adya, A. Sengupta, and S.V. Godbole, At. Spectrosc. 35, 25 (2014).

30. N. Pathak, V.C. Adya, S.K. Thulasidas, A. Sengupta, T.K. Seshagiri, and S.V. Godbole, At. Spectrosc. 35, 17 (2014).

31. A. Sengupta, and V.C. Adya, J. Radioanal. Nucl. Chem. 299, 2023 (2014).

32. T. Blazheva and A. Delijska Krushevska, Fresenius J. Anal. Chem. 338, 294 (1990).

33. A.G. Page, S.V. Godbole, S. Deshkar, Y. Babu, and B.D. Joshi, Fresenius J. Anal. Chem. 287, 304 (1977).

34. A.G.I. Dalvi, C.S. Deodhar, T.K. Seshagiri, M.S. Khalap, and B.D. Joshi, Talanta 25, 665 (1978).

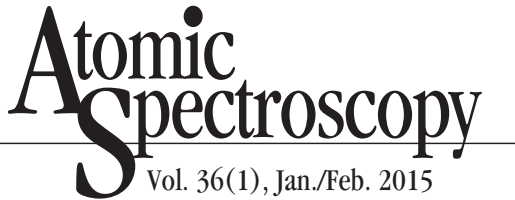

35. J.A. Goleb, J.P. Faris, and B.H. Meng, Appl. Spectrosc. 16, 9 (1962).

36. M.C.Bruzzoniti, E. Mentasti, C. Sarzanini, M. Braglia, G. Cocito, and J. Kraus, Anal Chim. Acta 332, 49 (1996). 